\title{
geodiversitas

Fossil turtles from the early Miocene localities of Mokrá-Quarry (Burdigalian, MN4), South Moravian Region, Czech Republic

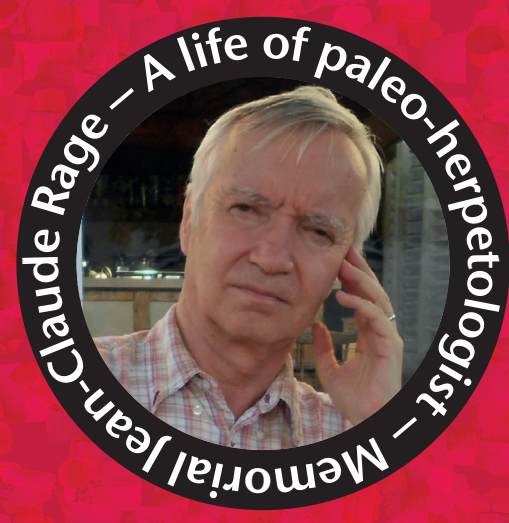

Àngel H. LUJÁN, Andrej ČERŇANSKÝ, Isaac BONILLA-SALOMÓN, Jakub BŘEEZINA \& Martin IVANOV
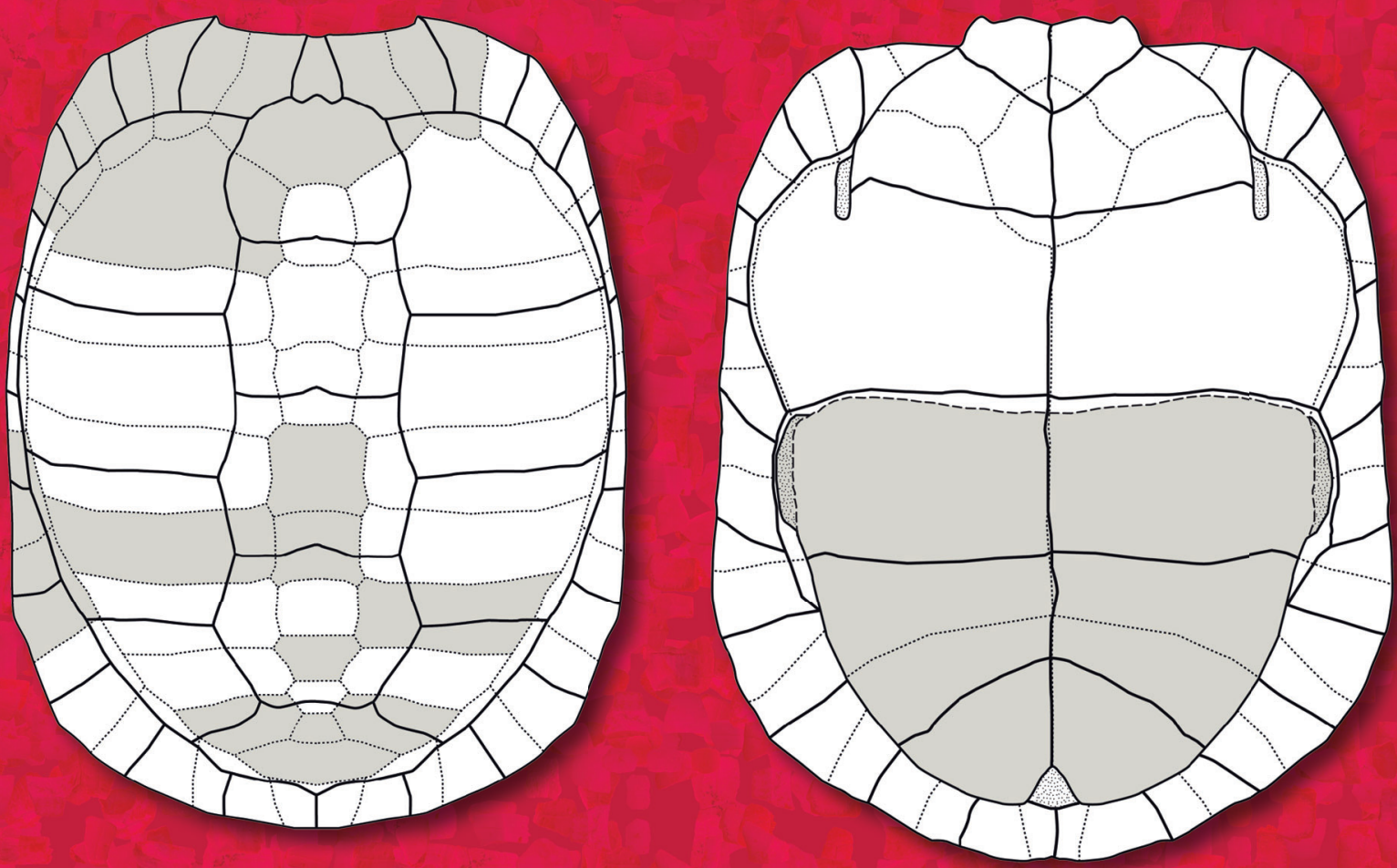
Directeur de LA PUBlication / PUblicAtion DIRECTOR : Bruno David,

Président du Muséum national d'Histoire naturelle

RÉDACTEUR EN CHEF / EDITOR-IN-CHIEF : Didier Merle

ASSISTANT DE RÉDACTION / ASSISTANT EDITOR: Emmanuel Côtez (geodiv@mnhn.fr)

Mise EN PAGE / PAGE LAYOUT: Emmanuel Côtez

COMITÉ SCIENTIFIQUE / SCIENTIFIC BOARD:

Christine Argot (Muséum national d'Histoire naturelle, Paris)

Beatrix Azanza (Museo Nacional de Ciencias Naturales, Madrid)

Raymond L. Bernor (Howard University, Washington DC)

Alain Blieck (chercheur CNRS retraité, Haubourdin)

Henning Blom (Uppsala University)

Jean Broutin (Sorbonne Université, Paris, retraité)

Gaël Clément (Muséum national d'Histoire naturelle, Paris)

Ted Daeschler (Academy of Natural Sciences, Philadelphie)

Bruno David (Muséum national d'Histoire naturelle, Paris)

Gregory D. Edgecombe (The Natural History Museum, Londres)

Ursula Göhlich (Natural History Museum Vienna)

Jin Meng (American Museum of Natural History, New York)

Brigitte Meyer-Berthaud (CIRAD, Montpellier)

Zhu Min (Chinese Academy of Sciences, Pékin)

Isabelle Rouget (Muséum national d'Histoire naturelle, Paris)

Sevket Sen (Muséum national d'Histoire naturelle, Paris, retraité)

Stanislav Štamberg (Museum of Eastern Bohemia, Hradec Králové)

Paul Taylor (The Natural History Museum, Londres, retraité)

COUVERTURE / COVER:

Réalisée à partir des Figures de l'article/Made from the Figures of the article.

Geodiversitas est indexé dans / Geodiversitas is indexed in:

- Science Citation Index Expanded (SciSearch $\left.{ }^{\circledR}\right)$

- ISI Alerting Services ${ }^{\circledR}$

- Current Contents ${ }^{\circledR}$ / Physical, Chemical, and Earth Sciences ${ }^{\circledR}$

- Scopus ${ }^{\circledR}$

Geodiversitas est distribué en version électronique par / Geodiversitas is distributed electronically by:

- BioOne ${ }^{\circledR}$ (http://www.bioone.org)

Les articles ainsi que les nouveautés nomenclaturales publiés dans Geodiversitas sont référencés par / Articles and nomenclatural novelties published in Geodiversitas are referenced by:

- ZooBank ${ }^{\circledR}$ (http://zoobank.org)

Geodiversitas est une revue en flux continu publiée par les Publications scientifiques du Muséum, Paris Geodiversitas is a fast track journal published by the Museum Science Press, Paris

Les Publications scientifiques du Muséum publient aussi / The Museum Science Press also publish: Adansonia, Zoosystema, Anthropozoologica, European Journal of Taxonomy, Naturae, Cryptogamie sous-sections Algologie, Bryologie, Mycologie, Comptes Rendus Palevol

Diffusion - Publications scientifiques Muséum national d'Histoire naturelle

CP $41-57$ rue Cuvier F-75231 Paris cedex 05 (France)

Tél. : 33 (0)14079 4805 / Fax: 33 (0)14079 3840

diff.pub@mnhn.fr / http://sciencepress.mnhn.fr

(C) Publications scientifiques du Muséum national d'Histoire naturelle, Paris, 2021

ISSN (imprimé / print): 1280-9659/ ISSN (électronique / electronic): 1638-9395 


\title{
Fossil turtles from the early Miocene localities of Mokrá-Quarry (Burdigalian, MN4), South Moravian Region, Czech Republic
}

\author{
Àngel H. LUJÁN \\ Masaryk University, Faculty of Science, Department of Geological Sciences, \\ 61137 Brno (Czechia) \\ and Comenius University in Bratislava, Faculty of Natural Sciences, \\ Department of Ecology, 84215 Bratislava (Slovakia) \\ and Institut Català de Paleontologia Miquel Crusafont, Universitat Autònoma de Barcelona, \\ Edifici ICTA, 08193 Cerdanyola del Vallès (Spain) \\ angel.lujan@icp.cat (corresponding author) \\ Andrej ČERŇANSKÝ \\ Comenius University in Bratislava, Faculty of Natural Sciences, \\ Department of Ecology, 84215 Bratislava (Slovakia) \\ cernansky.paleontology@gmail.com
}

Isaac BONILLA-SALOMÓN Department of Geology and Paleontology, Faculty of Natural Sciences, Comenius University, Mlynská dolina, Ilkovičova, 84215 Bratislava (Slovakia) salomon1@uniba.sk

Jakub BŘEZINA Moravian Museum, Department of Geology and Paleontology, 65937 Brno (Czechia) jbrezina@mzm.cz

Martin IVANOV Masaryk University, Faculty of Science, Department of Geological Sciences, 61137 Brno (Czechia) mivanov@sci.muni.cz

Submitted on 19 September 2019 | accepted on 30 March 2020 | published on 26 October 2021

KEY WORDS

Early Miocene, Burdigalian,

Testudo kalksburgensis, Chersine,

Czech Republic, Central Paratethys, Carpathian Foredeep Basin.
urn:Isid:zoobank.org:pub:04F82471-9F26-4935-97CE-1A286E08C958

Luján À. H., Čerňanský A., Bonilla-Salomón I., Březina J. \& Ivanov M. 2021. - Fossil turtles from the early Miocene localities of Mokrá-Quarry (Burdigalian, MN4), South Moravian Region, Czech Republic, in Steyer J.-S., Augé M. L. \& Métais G. (eds), Memorial Jean-Claude Rage: A life of paleo-herpetologist. Geodiversitas 43 (20): $691-707$. https://doi.org/10.5252/geodiversitas2021v43a20. http://geodiversitas.com/43/20

\section{ABSTRACT}

Fossil turtles from Mokrá-Quarry, South Moravia Region, Czech Republic, are described in this paper. Remains come from two already known karstic fissures uncovered in Mokrá-Western Quarry (1/2001 Turtle Joint and 2/2003 Reptile Joint), as well as three new karstic fissures from Mokrá-Western Quarry (TC/2001 and 4/2018) and Mokrá-Central Quarry (3/2005). All localities correspond to the early Miocene (Burdigalian: late Eggenburgian-Ottnangian MN4). The newly described material belongs to several turtle individuals, including over 100 shell elements, so the material studied here constitutes one of the largest samples in regards of the Czech Repub- 
MOTS CLÉS

Miocène inférieur,

Burdigalien,

Ptychogaster,

Testudo kalksburgensis,

Chersine,

Paratéthys centrale, bassin d'avant-chaîne des Carpates. lic fossil record. Most of these remains have been identified as Ptychogaster (Ptychogaster) sp. and Testudo (Chersine) cf. kalksburgensis Toula, 1896. However, three specimens presented here (i.e., one shell fragment and two postcranial bones) have been identified as a large tortoise (Testudinidae indet.). Turtle fauna is congruent with two ecological environments, including a dry karst landscape with open to dense steppe vegetation inferred for the heliophile testudinids, as well as freshwater masses to the semi-terrestrial ptychogasterid. Finally, this paper expands our knowledge of fossil turtle assemblages in Central Europe during the early Miocene.

\section{RÉSUMÉ}

Tortues fossiles des localités du Miocène inférieur de Mokrá-Quarry (Burdigalien, MN4), Moravie du Sud, République tchèque.

Les tortues fossiles de la carrière de Mokrá (Moravie du Sud, République tchèque) sont décrites dans cet article. Les restes proviennent de deux fissures karstiques déjà connues, découvertes dans la carrière de Mokrá-Western (1/2001 Turtle Joint et 2/2003 Reptile Joint), ainsi que de trois nouvelles fissures karstiques des carrières de Mokrá-Western (TC/2001 et 4/2018) et de MokráCentral (3/2005). Toutes les localités (MN4) correspondent au Miocène inférieur (Burdigalien: Eggenburgien supérieur-Ottnangien). Le matériel nouvellement décrit appartient à plusieurs individus de tortues et comprend plus de 100 éléments de carapace, ce qui en fait l'une des plus grandes collections de tortues fossiles de République tchèque. La plupart de ces restes ont été identifiés comme Ptychogaster (Ptychogaster) sp. et Testudo (Chersine) cf. kalksburgensis Toula, 1896. Cependant, trois spécimens présentés ici (un fragment de carapace et deux os postcrâniens) ont été identifiés comme appartenant à une grande tortue (Testudinidae indet.). Cette faune est congruente avec deux environnements écologiques, dont un paysage karstique sec à végétation steppique ouverte à dense d'après les testudinidés héliophiles, et des masses d'eau douce d'après le Ptychogaster semi-terrestre. Enfin, cet article complète nos connaissances sur les assemblages de tortues fossiles d'Europe centrale au cours du Miocène inférieur.

\section{INTRODUCTION}

Miocene turtle assemblages, which are frequent in Europe, are mostly found in basin deposits and karst areas. Currently, over ten early Miocene sites are known in Czechia, all of them Burdigalian in age (MN3-MN4: Fejfar 1974, 1990; Fejfar \& Kvaček 1993; Böhme \& Ilg 2003). However, majority of turtle reports are based on unpublished remains (e.g., $\mathrm{PhD}$ 's or online databases), or are recovered from faunal list in publications (Rzehak 1912, 1919; Čtyroký et al. 1973; Böhme \& Ilg 2003; Kvaček et al. 2004; Schäfer 2013; Ivanov 2015; Bonilla-Salomón et al. 2021). Therefore, these records should be treated with caution, as some of them cannot be verified based on available sources. According to mammal fauna, the oldest early Miocene turtle occurrences come from the Most Basin (Ohře/Eger Graben, NW Czechia), and more specifically from the limestone quarry of Tuchořice and deposits of the main brown coal seam of the Ahníkov/ Merkur-North Mine (both early Burdigalian: Eggenburgian, MN3). Otherwise, the youngest locality in Czechia would be Dolnice site (Burdigalian: late Eggenburian-Ottnangian, MN4) placed in the Cheb Basin (Fejfar 1974, 1990). In fact, Dolnice has been the only Czech site studied in detail yielding fossil turtles, including descriptions and figures (see Młynarski \& Roček 1985).
An assemblage formed by five karstic localities from MokráQuarry (South Moravia Region) is studied here in detail. It is more-or-less biostratigraphically comparable to the Dolnice localities. This large open cast mine currently consists of three quarries named as follows: The Western (MWQ); Central (MCQ) and Eastern (MEQ) respectively (Fig. 1). Unlike squamates, amphibians and mammals, turtle remains have been recovered in two of the three quarries (MWQ and MCQ: Ivanov et al. 2006; Ivanov 2008). Palaeontological research into Neogene fillings of fossiliferous karst joints from Western Quarry (1/2001 and the 2/2003) started at the beginning of the 21 st century, coinciding with commercial extraction work (Ivanov \& Musil 2004; Ivanov et al. 2006). During that time, research of the early Badenian marine deposits, which are placed in the valley between the Western and Central sectors, was carried out from analysis of several boreholes (Ivanov et al. 2006). More recently, Mokrá-Quarry has provided three more turtle localities, which are named as follows: TC/2001 and 4/2018 both from MWQ; and 3/2005 from MCQ. It is remarkable that the localities from MokráQuarry have yielded one of the most abundant and complete herpetofauna of Central Europe, and more specifically from the early Miocene (MN4), including: amphibians (Bufonidae, Pelobatidae, Proteidae, Ranidae, and Salamandridae: Ivanov 2008); squamates (Lacertidae, Amphisbaenia, ?Scincoidea, 

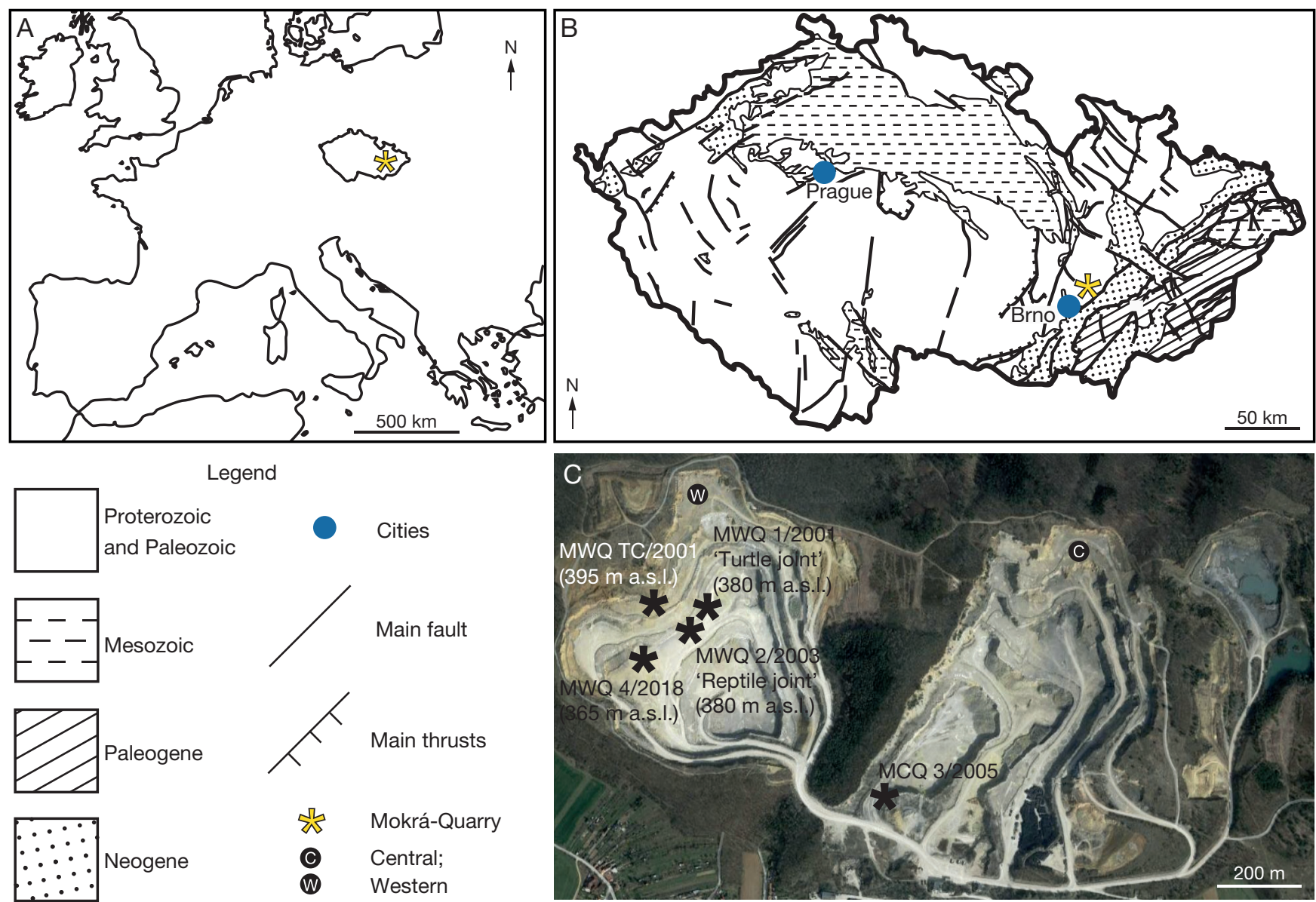

FIG. 1. - Approximate geographical position of Mokrá-Quarry (A). Schematic geological map of the Czech Republic (B). Position of the five Mokrá-Quarry localities that have yielded fossil turtle remains $(\mathbf{B}, \mathbf{C})$.

Anguidae, Varanidae, Boidae, Colubridae, Elapidae, Pythonidae, and Viperidae: Ivanov et al. 2018, 2020) and Testudines (Geoemydidae and Testudinidae: Luján et al. 2017a; BonillaSalomón et al. 2021).

The first aim of this paper is to study the turtle composition of all five Mokrá-Quarry localities. Secondly, we provide descriptions and taxonomy of turtles based on all remains. Finally, we discuss the palaeoclimatic conditions given the new data obtained from these fossil turtles.

\section{AGE AND GEOLOGICAL BACKGROUND}

Remains described in this paper come from Mokrá-Quarry located about $12 \mathrm{~km}$ ENE of Brno. It is placed in the SE part of the Moravian Karst, on the Mokrá Plateau (Fig. 1). It lies in a close proximity of the margin fault of the West Carpathian Foredeep. The Mokrá Plateau is mainly formed by the Vilémovice Limestone of the Macocha Formation (GivetianFrasnian), which is quite massive and biodetritic (Hladil et al. 1987; Ivanov et al. 2006). However, Mokrá-Quarry is mainly made up by Devonian carbonates (Hády-Ř́ćcka Limestones of the Líšen Formation) passing into the Lower Carboniferous flysch facies, both often affected by several phases of folding as a result of the Variscan orogeny (Rez et al. 2011). The karstic landscape of the Mokrá Plateau is then rather the result of the chemical character of the carbonates, and more specifically of the processes of pressure dissolution, as well as of the mechanical deformations of such carbonates (Hladil et al. 1987; Rez 2003). Neither Mesozoic nor Palaeogene sediments are present from the whole southern part of the Moravian Karst: instead, Neogene deposits are abundant. They consist of freshwater and brackish sediments (late Eggenburgian to Ottnangian), as well as deltaic sand, gravel and marine clay (Badenian). During the Karpatian, marine sediments dominated the Moravian part of the Carpathian Foredeep, although deposits of that age are not preserved in the southern part of the Moravian Karst (Petrová et al. 2001). As the palaeobathymetric analysis of the Badenian sediments pointed out, marine sedimentation in the foredeep moved far to the northwest. Consequently, Badenian transgression reached its maximum affecting most of the Drahany Upland and the Moravian Karst (Procházka 1899; Brzobohatý 1997). Remnants of such sediments are preserved in karst joints and open faults of the Mokrá Plateau, which are clearly recognized in the Vilémovice Limestone (e.g., limonitised layers or alternatively for containing oyster fragments: Hladil et al. 1987). More recently, this geological episode was also confirmed 
by a number of sampling boreholes, which are rich mainly in foraminiferans, ostracods, sponge spicules and otoliths (Brzobohatý et al. 2000; Ivanov et al. 2006).

Fossil mammals recovered from Mokrá-Quarry include remains of both micro- and macro-mammals. Thus far, only two localities from MWQ (1/2001 and 2/2003) have been preliminary studied. According to Ivanov et al. (2006), the first two fissures were reported including macro-mammals only, further indicating that these localities are of the early Miocene in age (MN4). Shortly after, Sabol et al. (2007) confirmed the age for both fissures based on the micromammalian assemblage. As for rest of the localities (i.e., TC/2001, 4/2018 and 3/2005), we tentatively attributed them to the early Miocene (MN4, Ottnangian) as well, due to the lack of more detailed studies.

\section{MATERIAL AND METHODS}

Turtle remains of the five fossiliferous karst joints were recovered during field campaigns (2002-2019). Thus far, over 100 specimens of turtles have been recovered, of which a geoemydid and two testudinids (i.e., one small and another large) were identified. In order to recover shell fragments and bones mixed in calcareous sand and clays, all sediment was washed in sieves of 0.5-2.0 mm mesh (Ivanov et al. 2006). $\mathrm{H}_{2} \mathrm{O}_{2}$ in aqueous solution was employed to dissolve the rock fragments and clay matrix, followed by the washing of the different samples with a regulated stream of running water. The material is currently held in the collections of the Department of Geological Sciences at Masaryk University (Brno, Czechia). It should be noted that some turtle remains were left unstudied, since they consisted mainly of poorly preserved carapace and plastron fragments (i.e., most of them juvenile individuals), and therefore, a precise anatomical identification for them was impossible.

\section{ABBREVIATIONS}

Institutions

IGUW Institut für Geologische Wissenschaften, Universität Wien (formerly Institut für Geologie), Vienna, Austria; Pal Department of Geological Sciences, Faculty of Science, Masaryk University, Brno, Czech Republic.

\section{Localities \\ 1/2001 Mokrá-Western Quarry 1/2001 Turtle Joint (MN4); 2/2003 Mokrá-Western Quarry 2/2003 Reptile Joint (MN4); 3/2005 Mokrá-Central Quarry 3/2005 (MN4); \\ TC/2001 Mokrá-Western Quarry Turtle Cave (MN4); \\ 4/2018 Mokrá-Western Quarry 4/2018 (MN4).}

\section{TERMINOLOGY}

Anatomical shell nomenclature employed throughout the descriptions is based on Zangerl (1969), whereas the taxonomy used follows Luján et al. (2014, 2016, 2017b).

\section{SYSTEMATIC PALAEONTOLOGY}

\author{
Order TESTUDINES Linnaeus, 1758 \\ Family GEOEMYDIDAE Theobald, 1868 \\ Subfamily Ptychogasterinae De Stefano, 1903
}

Ptychogaster Pomel, 1847

TYPe SPECIES. - Ptychogaster emydoides Pomel, 1847.

$$
\text { Ptychogaster (Ptychogaster) sp. }
$$

(Figs 2; 3)

LOCALITIES. -MWQ1/2001, MWQ2/2003, MWQTC/2001, MWQ4/2018 and MCQ3/2005.

Studied MATerial. - Czech Republic. South Moravia Region, Mokrá-Quarry, carapace remains (Fig. 2A-R'): Pal. 1300, nuchal and left peripherals 1-3; Pal. 1301, nuchal; Pal. 1302, neural 4; Pal. 1303, neural 5; Pal. 1304, neural 7; Pal. 1305, suprapygal 1; Pal. 1306, suprapygal 2; Pal. 1307, left costal 1; Pal. 1308, right costal 6; Pal. 1309, right costal 6; Pal. 1310, left costal 8; Pal. 1311, right costal 8; Pal. 1312, right peripheral 1; Pal. 1313, left peripheral 7; Pal. 1314, left peripheral 8. Plastral remains (Fig. 3A-R): Pal. 1315, left hypoplastron; Pal. 1316, right hypoplastron; Pal. 1317, right hypoplastron; Pal. 1318, left xiphiplastron.

\section{DESCRIPTION}

The ptychogasterid material (Pal. 1300-1318) from MokráQuarry consists of numerous disarticulated plates, which present preserved parts of the almost the entire shell. However, some plates are missing from the carapace (i.e., pygal, costals 2-4 and 7, neurals 1-3 and both medial and posterior peripherals). The plastron is represented only by the hypoplastron and the xiphiplastron. The following description is based on all available material, however, not all preserved plates are depicted in Figures 2 and 3. According to the dimensions of the nuchal plate (Pal. 1300-1301), costals (Pal. 1307-1311) and peripherals (Pal. 1312-1314), the shell would have been relatively large (> $20 \mathrm{~cm}$ : Figs $2 ; 3)$. Ornamentation of both carapace and plastron external surfaces is absent. As it is typical for Ptychogaster plates, dermal grooves are well developed. Unlike Testudo, neither growth lines nor sutures (i.e., completely fused to each other: see e.g., Fig. 2A-D) are preserved, so it is impossible to evaluate them.

The nuchal plate is hexagonal in outline, wider than long (Pal. 1301: Fig. 2E-H). It contacts the first pair of peripherals, the first pair of costals and the neural 1 . The anterior border possesses a shallow nuchal notch, affecting the nuchal border and the first peripherals (Pal. 1300: Fig. 2A, B). The anteroposterolateral sides of the nuchal are rather equal in length, whereas the posterior border is narrow and slightly convex anteriorly (Fig. 2E, F). In lateral view, the nuchal is vaguely curved (Fig. 2I, J). Two transversal thickenings are

FIG. 2. - Carapace remains of Ptychogaster (Ptychogaster) sp. from Mokrá-Quarry localities: A-D, Pal. 1300 (nuchal and peripherals 1-3); A, B, dorsal; C, D, visceral; E-L, Pal. 1301 (nuchal); E, F, dorsal; G, H, visceral; I, J, left lateral; K, L, anterior; M, N, Pal. 1302 (neural 4); M, dorsal; N, visceral; O-Q, Pal. 1303 (neural 5); O-P, dorsal; Q, visceral; R, S, Pal. 1304 (neural 7); R, dorsal; S, visceral. T, U, Pal. 1305 (suprapygals 1-2); T, dorsal; U, visceral; V, W, Pal. 1307 (costal 1); V, dor- 


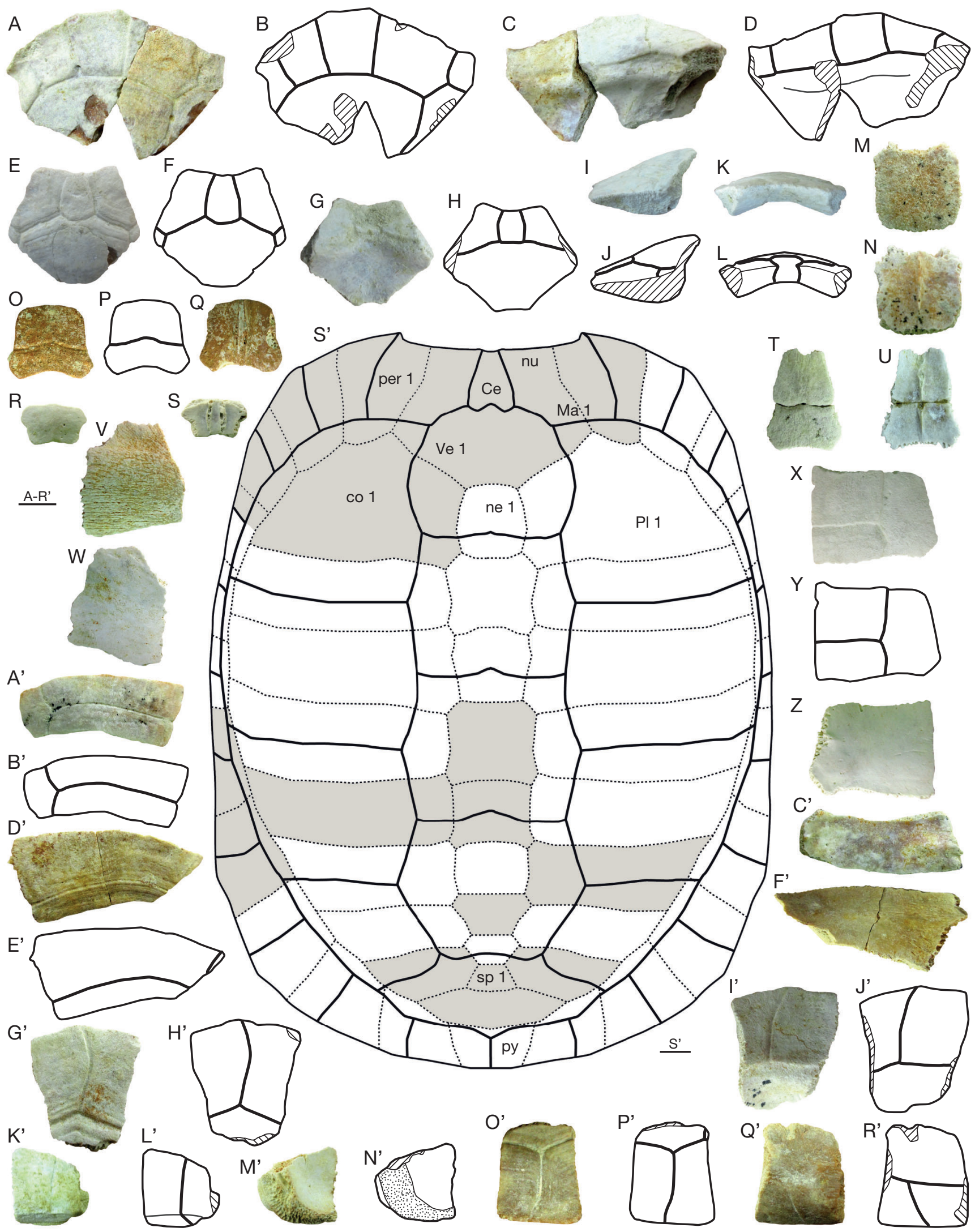

sal; W, visceral; X-Z, Pal. 1308 (costal 5); X, Y, dorsal; Z, visceral; A'-C', Pal. 1309 (costal 6); A', B', dorsal; C', visceral; D'-F', Pal. 1310 (costal 8); D', E', dorsal; F', visceral; G'-J', Pal. 1312 (peripheral 1); G', H', dorsal; I', J', visceral; K'-N', Pal. 1313 (peripheral 7); K', L', dorsal; M', N', visceral; O'-R', Pal. 1314 (peripheral 8); O', P', dorsal; Q', R', visceral views; S', reconstruction of carapace. Thick lines indicate to scute sulci, dotted lines sutures and oblique lines denote missing plate portions. Abbreviations: Ce, cervical; co, costal; Ma, marginal; ne, neural; nu, nuchal; per, peripheral; PI, pleural; py, pygal; sp, suprapygal; Ve, vertebral. Scale bars: $1 \mathrm{~cm}$. 
A
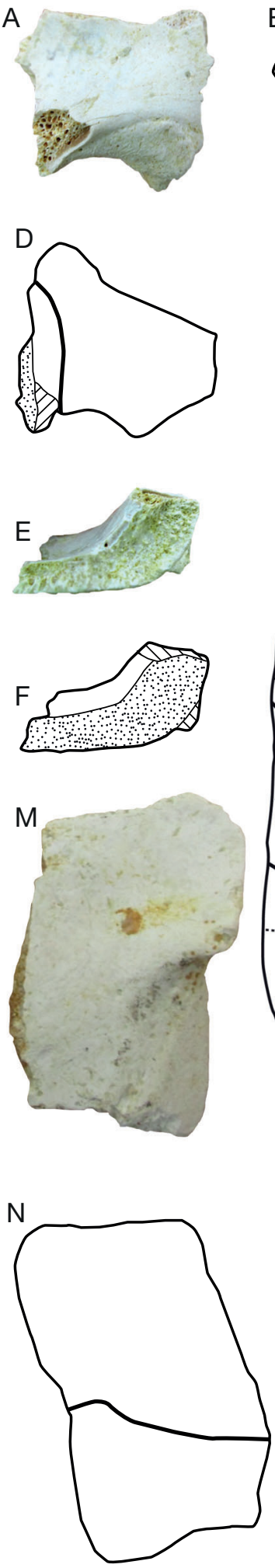

Q

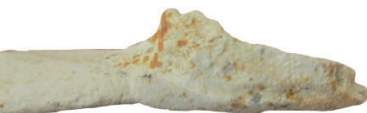

O
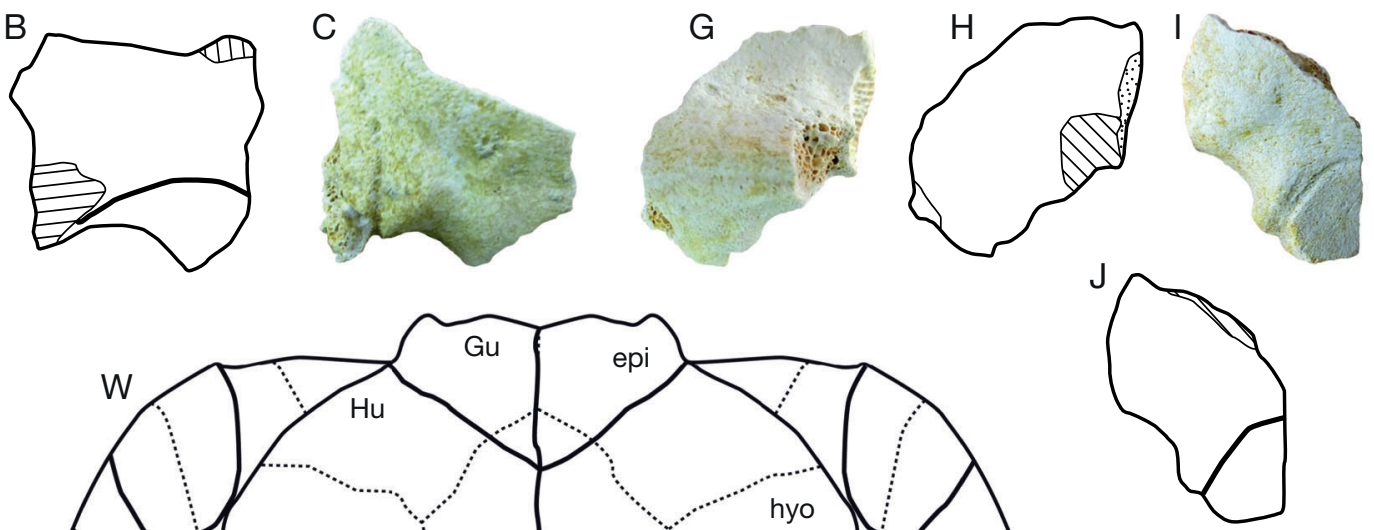

K
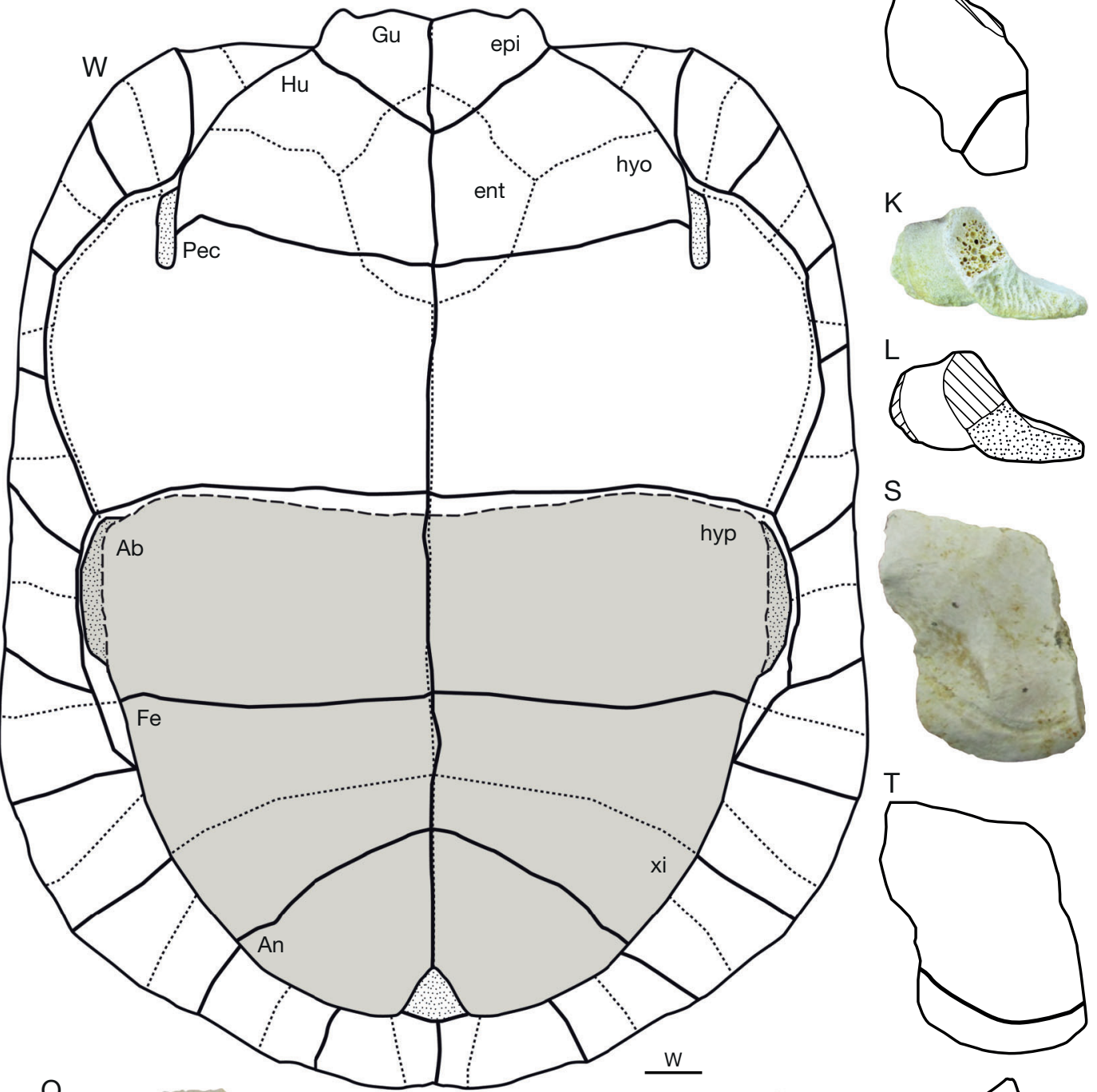

$S$
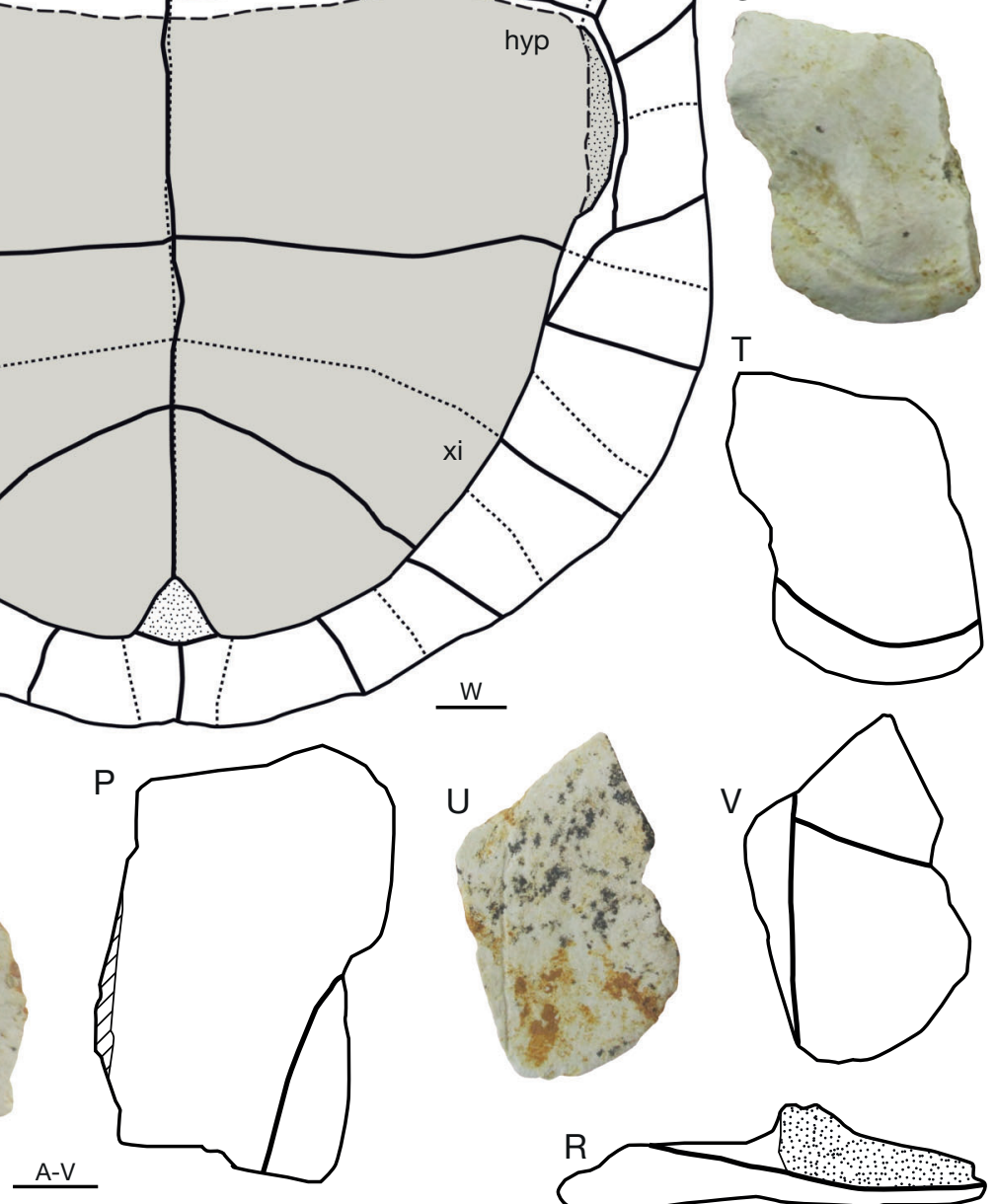

FIG. 3. - Plastral remains of Ptychogaster (Ptychogaster) sp. from Mokrá-Quarry localities: A-F, Pal. 1315 (hypoplastron); A, B, visceral; C, D, ventral; E, F, left lateral; G-L, Pal. 1316 (hypoplastron); G, H, visceral; I, J, ventral; K, L, right lateral; M-R, Pal. 1317 (hypoplastron); M, N, visceral; O, P, ventral; Q, R, right lateral; S-V, Pal. 1318 (xiphiplastron); S, T, visceral; U, V, ventral views; W, reconstruction of plastron. Thick lines indicate to scute sulci, dotted lines denote plate sutures, dashed lines denote completely ligamentous kinesis (between hypoplastra and peripherals and the hinge between hyoplastron and hypoplastron), and oblique lines indicate missing plate portions. Abbreviations: Ab, abdominal; An, anal; ent, entoplastron; epi, epiplastron; hyo, hyoplastron; hyp, hypoplastron; $\mathbf{F e}$, femoral; Gu, gular; Hu, humeral; Pe, pectoral; xi, xiphiplastron. Scale bars: $1 \mathrm{~cm}$. 
developed on the internal surface of this bone (Fig. 2C, D, $2 \mathrm{G}-\mathrm{L}$ ). The cervical scute is present anteriorly, both dorsally and viscerally. It is a relatively large and trapezoidal element that is longer than wide (Fig. 2E, F). The lateral edges of the cervical are slightly curved medially both in dorsal and visceral sides (Fig. 2A, B, E-H). The overlap of this scute is less developed on the ventral surface (Fig. 2G, H).

According to the preserved neural plates, an alternating between octagonal and hexagonal plates forms the neural series: neural 4 octagonal (Pal. 1302: Fig. 2M, N) and neural 5 and 7 hexagonal with short sides behind (Pal. 1303-1304: Fig. 2O-S). A weak medial keel develops on the neural 7 (Pal. 1304: Fig. 2R, S) and the suprapygals 1-2 (Pal. 1305-1306: Fig. $2 \mathrm{~T}, \mathrm{U})$. In visceral view, remains of the thoracic vertebrae attachments are present in all neural plates (Fig. 2N, Q, S).

The suprapygal plate 1 is trapezoidal with a wider posterior part (Pal. 1305: Fig. 2T). The anterior border is concave, whereas the posterior one is slightly convex. It contacts the neural 8 anteriorly, costals 8 laterally and suprapygal 2 posteriorly. Suprapygal 2 is hexagonal, wider than long, and much wider than suprapygal 1 (Fig. 2T, U). It contacts the suprapygal 1 and the posteromedial sides of costals 8 anteriorly, peripherals 11 laterally and pygal posteriorly. The anterolateral sides of the suprapygal 2 are slightly longer anteroposteriorly, compared to the posterolateral ones. The posterior side is vaguely convex anteriorly (Fig. 2T, U).

The vertebral scute series is partially preserved, which is quadrangular and slightly narrower than the costal series. Vertebral 1 contacts the cervical and marginals 1-2 anteriorly (Fig. 2B, F). It seems to be lyre-shaped and covers the lateral corners of the nuchal and costals 1 (Pal. 1300-1301: Fig. 2A, $\mathrm{B}, \mathrm{E}, \mathrm{F})$. According to preserved portion of the vertebral 3, it expanded at least on costals 5 and neural 5 (Fig. 2X, Y). The sulcus between the vertebrals 3-4 is wavy in its medial part, and more specifically in the part that is crossing the neural 5 (Fig. 2O, P). Vertebral 4 likely contacts the vertebral 3 anteriorly, pleurals 3-4 laterally and vertebral 5 posteriorly (Fig. 2P, A', B', D', E'). Vertebral 5 is the widest vertebral scute, contacting with the vertebral 4 anteriorly, pleural 4 anterolaterally and marginals $11-12$ posteriorly. It expands on costals 8 , neural 8 , peripheral 12 and pygal, and therefore covers the entire surface of the suprapygals 1-2.

Although not fully preserved costals, the costal plate 1 is much longer than the rest of costal (Pal. 1307: Fig. 2V, W). It is trapezoidal and always contacts the peripheral plates 1-3 anterolaterally, nuchal anteromedially and neurals 1-2 medially. The anterior border is sinuous to articulate with the corresponding peripherals. Costal 6 is similar in regards of its shape, being much wider than long (Pal. 1308-9: Fig. 2X-B'). The medial side of Pal. 1308 shows a short anteromedial and long posteromedial sides (Fig. 2X-Z). However, the medial side of Pal. 1308 is most likely rounded (Fig. 2A'-C'). Costal 8 is narrow, slightly wider than long, contacting the costal 7 anteriorly, neural 8 and suprapygal 1 medially, and suprapygal 2 and peripherals 11-12 posteriorly (Pal. 1310-11: Fig. 2D'-F'). The pleural scutes are not preserved with the exception of the first one. The marginopleural sulcus is entirely situated on peripheral plates, at least in both anterior and posterior part of the carapace (Fig. 2A, B, E, F, V, A', B', D', E').

The peripheral plates $1-3$ are longer than wide and slightly trapezoidal (Fig. 2A-D, G'-J'). They are completely fused together (i.e., sutures are not visible) and crossed not only by the intermarginal sulcus, but also by the pleuro-marginal sulcus, unlike in Testudo. Peripherals 1-2 are prominent in anterior direction in Pal. 1300. Peripheral 7, which is partially preserved, is rectangular (Pal. 1313: Fig. 2K'-N'). In internal view, it displays a rough elongated area for the cartilaginous union of the inguinal process (Fig. 2M', N'). Pal. 1313 is the last peripheral involved in the shell bridge and also displays a weak lateral ridge on its external side. Peripheral 8 is rectangular and hosts both the pleuromarginal sulcus and intermarginal sulci (i.e., between marginals 8-9), which are situated far from the costoperipheral suture (Pal. 1314: Fig. 2O'-R'). The marginal scute 1 is rectangular, slightly wider than long, whereas marginal 2 is trapezoidal. Marginal 3 is approximately as wide as long. Marginal 8, the only complete scute from the bridge area, is rectangular and higher than wide. The ventral overlap of all preserved marginals is well developed.

The preserved portion of the hyo-hypoplastral hinge is straight and approximately transversal (Pal. 1377: Fig. 3M-P), which is located at the mid of the peripheral 6 . The hypoplastron contact anteriorly with the hypoplastron through a hinge and laterally with the peripherals 6-7 through a completely ligamentous union in the inguinal process (Pal. 131517: Fig. 3A-R). The visceral overlap of both abdominal and femoral scutes on hypoplastra is well developed (Fig. 3M, N). The xiphiplastron is trapezoidal and its posterior tip is rather rounded. The abdominofemoral sulcus, developed on the ventral surface of each hypoplastron, is concave (Fig. 2N, O). Moreover, the latter does not reach the inguinal process laterally, but is located slightly below it. The femoroanal sulcus is oblique, whereas the anal scute is triangular with rounded lateral borders (Fig. 2S-V). The dorsal overlap of the anal scute is moderately developed (Fig. 2S, T).

\section{REMARKS}

Ptychogasteridae is a geoemydid family which includes turtles of medium body size. This clade originated in Europe during the Eocene and its members are characterized mainly by a plastral kinesis (Lapparent de Broin 2001; Claude 2006). Thus, the anterior part of the plastron is firmly connected to the carapace, whereas the posterior one is movable thanks to a hinge situated between hyo- hypoplastra and peripherals 6 . Some studies claimed that ptychogasterids constitute a monophyletic clade diagnosable by several synapomorphies (Hervet 2004a, b, 2006). However, the inclusion within ptychogasterids of non-kinetic extinct geoemydids genera, such as Merovemys, Clemmydopsis and Hummelemys, has been questioned (see Claude \& Tong 2004). A more comprehensive phylogenetic analysis would be required in the future to know what genera belong to subfamily Ptychogasterinae, as well as to further clarify which are the closest extinct relatives of the latter. 

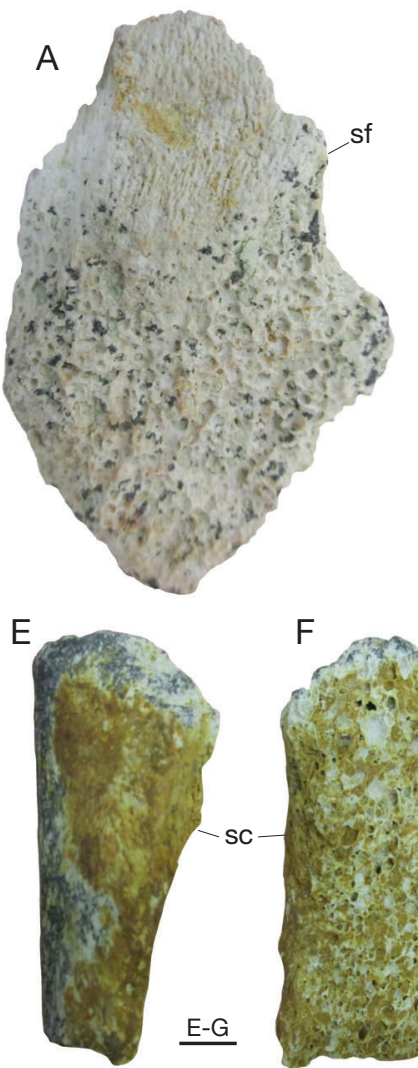

$\underline{E-G}$

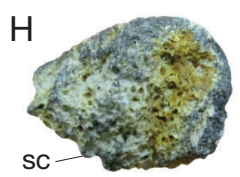

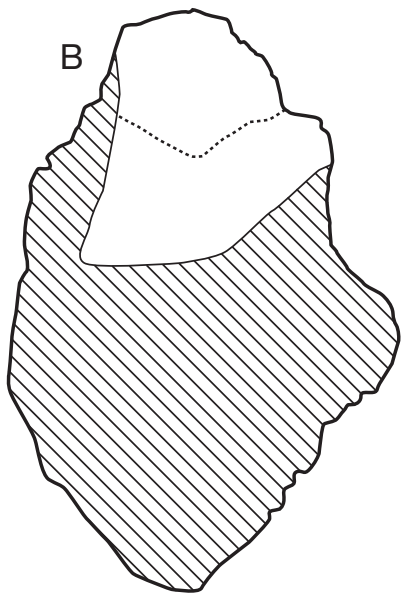
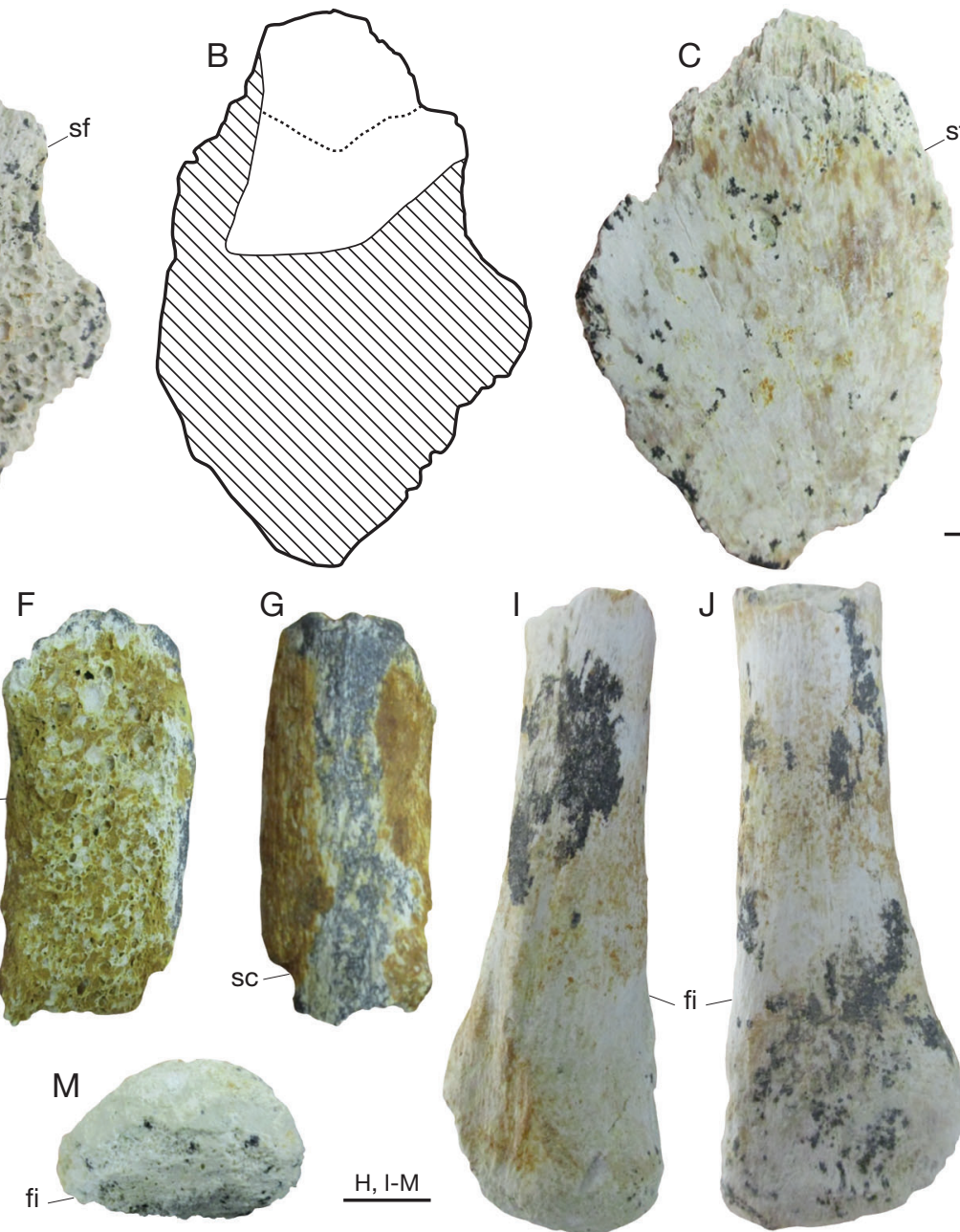

$\mathrm{H}, \mathrm{I}-\mathrm{M}$
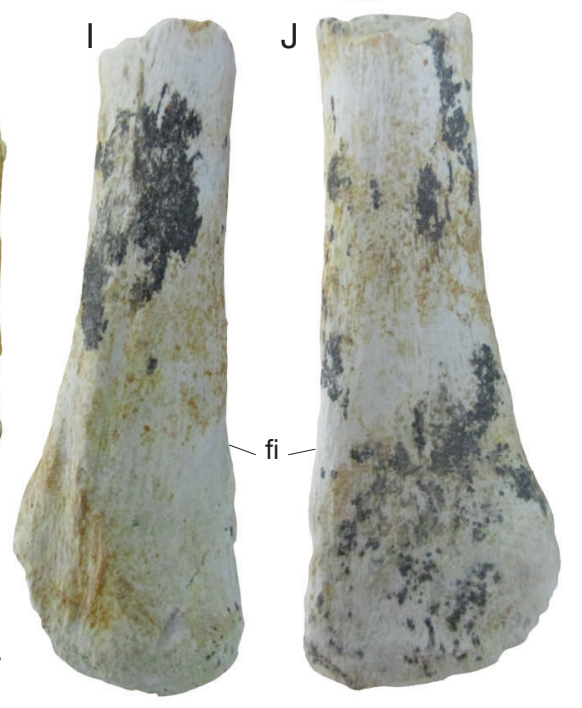
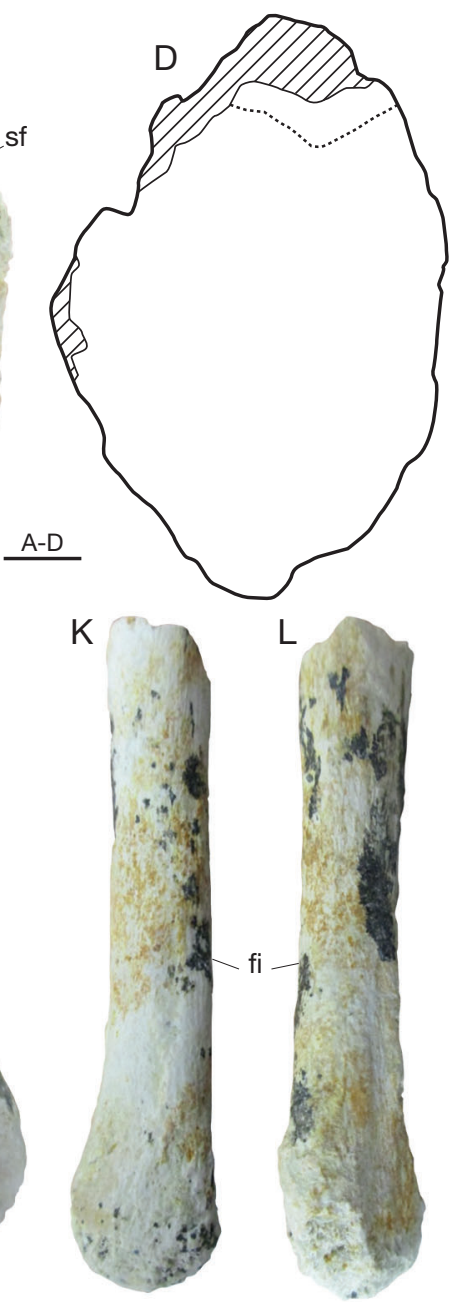

FIG. 4. - Shell and postcranial remains of Testudinidae indet. from MWQ4/2018: A-D, Pal. 1363 (shell fragment); A, B, dorsal; C, D, visceral; E-H, Pal. 1364 (scapula); E, lateral; F, medial; G, anterior; H, dorsal; I-M, Pal. 1365 (fibula); I, dorsal; J, ventral; K, posterior; L, anterior; M, lateral views. Dotted lines indicate plate sutures and oblique lines denote missing plate portions. Abbreviations: fi, fibula; sc, scapula; sf, shell fragment. Scale bars: $1 \mathrm{~cm}$.

As for the genus Ptychogaster, it was originally erected by Pomel (1847) from the early Miocene (MN2) of Saint-Gerandle-Puy, France. Two subgenera are currently distinguished within Ptychogaster: P. (Ptychogaster); and P. (Temnoclemmys). Ptychogaster (Ptychogaster) emydoides Pomel, 1847 (i.e., type species of subgenus Ptychogaster) has a complex taxonomical and nomenclatural history, with many junior subjective synonyms (Schäfer 2013; Luján et al. 2014). Although one revision of the genus Ptychogaster has recently been performed, the results of this PhD thesis are still unpublished (Schäfer 2013).

\section{Subfamily TeSTUdininAe Batsch, 1788}

Testudinidae indet. (Fig. 4)

LOCALITIES. - MWQ4/2018.

STUdied MATERIAL. - Czech Republic. South Moravia Region, Mokrá-Quarry, shell and postcranial remains (Fig. 4A-M): Pal. 1363, shell fragment; Pal. 1364, scapula (i.e., anterodorsal process fragment); Pal. 1365, right fibula.

\section{DESCRIPTION}

Only a shell fragment formed by two portions of plates is known (Fig. 4A-D). Pal. 1363 corresponds most likely to a carapace portion, but it is poorly preserved and is not possible to assess this confidently. The length and maximum width of the preserved plate fragment is $6 \mathrm{~cm}$. The external part is completely smooth and is not crossed by any sulcus (Fig. 4C, D). A suture is recognized on top of plate, which is concave and approximately $2 \mathrm{~cm}$ wide. A partial bone, belonging to the shoulder girdle, has been identified (Pal. 1364: Fig. 4E-H). Only the anterodorsal process fragment is preserved. Pal. 1364 is subcylindrical in cross-section and distally rounded. The distal surface ends in a rough rounded area to join with the visceral part of the carapace (Fig. $4 \mathrm{H}$ ). The hind limb skeleton is restricted to one partial fibula (Fig. 4I-M) that is elliptical in cross-section. Its distal articular surface is slightly small, oval and convex (Fig. 4M). Both postcranial bones are poorly preserved and no significant details can be discerned.

\section{REMARKS}

Fossil remains of giant tortoises are not very common in Miocene assemblages of Central Europe; their record 
being limited to few localities from Austria, Germany, Hungary and Switzerland (Alba et al. 2010, 2011; Carmona et al. 2011; Luján 2015). Loveridge \& Williams (1957) proposed that all European giant tortoises should be transferred into the extant genus Geochelone. This proposal was adopted for some time, and consequently, large tortoise remains in Europe are still frequently referred to in the literature as Geochelone sp. (e.g., Auffenberg 1974; Młynarski 1976). However, current phylogenies do not support a close relationship between Mio- Pleistocene large tortoises and Geochelone. More recently, Bourgat \& Bour (1983) referred all giant fossil tortoises to the genus Cheirogaster. Most subsequent works accepted this genus attribution (e.g., Luján et al. 2010, 2014), until recently when Pérez-García \& Vlachos (2014) proposed that European Neogene giant tortoises constitute a clade that is more derived than the type species of Cheirogaster. To allocate these taxa, Pérez-García \& Vlachos (2014) erected the genus Titanochelon, with Ti. bolivari (HernándezPacheco, 1917) as its type species. This genus is characterized by a shell reaching over $100 \mathrm{~cm}$ and the fusion of marginal scutes 12 (i.e., constituting a supracaudal scute). However, the evolution of gigantism amongst fossil tortoises is clearly a homoplastic phenomenon, mainly related to insular conditions, or adaptation to either global or local environmental changes (Kear 2010; Luján et al. 2010, 2017b; Itescu et al. 2014). Similarly, the fusion of marginal scutes 12 occurs in many extant and extinct genera and cannot be considered autapomorphic for the genus Titanochelon. In summary, the taxonomy of the Miocene giant tortoises of Europe is still a subject of debate and will require improvement of existing data matrix (e.g., including more skull characters) in order to decipher the phylogenetic relationships of Titanochelon (Luján et al. 2017b).

\section{Genus Testudo Linnaeus, 1758}

Subgenus Chersine Merrem, 1820

TYPe SPECIES. - Testudo (Chersine) hermanni Gmelin, 1789.

Testudo (Chersine) cf. kalksburgensis Toula, 1896

(Figs 5; 6)

LOCALITIES. — MWQ1/2001, MWQ2/2003, MWQTC/2001, MWQ4/2018 and MCQ3/2005.

Studied Material. - Czech Republic. South Moravia Region, Mokrá-Quarry, carapace remains (Fig. 5A-V'): Pal. 1319, nuchal; Pal. 1320, nuchal; Pal. 1321, nuchal; Pal. 1322, neural 4; Pal. 1323, neural 6; Pal. 1350, neural 7; Pal. 1322, neural 4; Pal. 1324, pygal; Pal. 1325, pygal; Pal. 1328, right costal 1; Pal. 1326, left costal 1; Pal. 1327, left costal 1; Pal. 1329, right costal 2; Pal. 1330, left costal 3; Pal. 1331, left costal 6; Pal. 1332, left peripheral 1; Pal. 1333, right peripheral 1; Pal. 1334, left peripheral 2; Pal. 1335, left peripheral 2; Pal. 1336, right periph- eral 2; Pal. 1337, right peripheral 2; Pal. 1338, right peripheral 5; Pal. 1339, left peripheral 7; Pal. 1340, right peripheral 7; Pal. 1341, right peripheral 8; Pal. 1342, left peripheral 9; Pal. 1343, right peripheral 9; Pal. 1344, left peripheral 10; Pal. 1345, left peripheral 10; Pal. 1346, left peripheral 10; Pal. 1347, left peripheral 11; Pal. 1348, left peripheral 11. Pal. 1349, left peripheral 11. Plastral remains (Fig. 6A-H'): Pal. 1351A, left epiplastron; Pal. 1352, entoplastron; Pal. 1353, entoplastron; Pal. 1354, entoplastron; Pal. 1351B, right hyoplastron; Pal. 1355, right hyoplastron; Pal. 1356, left hypoplastron; Pal. 1357, right hypoplastron; Pal. 1358, right hypoplastron; Pal. 1359, right hypoplastron; Pal. 1360, left xiphiplastron; Pal. 1361, left xiphiplastron; Pal. 1362, left xiphiplastron.

\section{DESCRIPTION}

Testudo material recovered from Mokrá-Quarry consists mainly of disarticulated plates (Pal. 1319-1362). However, some costals, peripherals and neurals are missing. They belong to a medium-sized Testudo, which reached approximately $20-25 \mathrm{~cm}$. The following description is based on the entire available material, but not all the plates are depicted (Figs 5; 6). Most of the dermal grooves and sutures are visible. There is no ornamentation on the carapace or plastron. Growth lines are discernible in some carapace plates, and more specifically in both peripheral and costal plates (e.g., Fig. 5K, A').

The nuchal plate is hexagonal, slightly wider than long, and its anterior edge is pointed (Fig. 5A-D). The posterolateral edges are straight, whereas the anterior ones are curved in medial direction. A transverse thickening is recognizable on the visceral surface of the nuchal (Fig. 5C, D). The cervical scute is longer than wide and its total length constitutes less than a half of the nuchal plate. It is well developed both dorsally and viscerally according to the three preserved plates (Pal. 1319-21). The anterior edge is narrower than the posterior ones. The lateral sulci are almost straight and parallel to each other (Fig. 5A, B).

Only three neurals plates are preserved, which vary in shape from subsquare (i.e., neural 4) to hexagonal (i.e., neurals 6 to 7: Fig. 5E-G). It is noteworthy that none of them is more than twice as wide as long, and that they are encroached transversally by the intervertebral sulci (Fig. 5E-G).

The pygal plate is trapezoidal with slightly concave anterolateral margins. Its external surface is moderately convex, whereas its internal one is rather concave (Fig. $5 \mathrm{H}-\mathrm{J}$ ). The marginal scutes 12 are missing, and therefore the supracaudal scute is not divided by a sagittal groove (Pal. 1324-25: Fig. 5H-J). The shape of the vertebral scutes cannot be ascertained with a confidence because they are incomplete.

Only five of the eight costal plates are present (i.e., costals 1-3 and 5-6), which are trapezoidal. Costals 1 and 3 host the intervertebral sulci (Fig. 5K, L, O, P, W'), whereas the costals 2 and 6 host the interpleural sulci (Fig. $5 \mathrm{M}$, $\left.\mathrm{N}, \mathrm{Q}, \mathrm{R}, \mathrm{W}^{\prime}\right)$. The pleural scutes are poorly preserved, so no significant details can be discerned. Despite this, the pleuromarginal sulcus coincides with the costoperipheral suture all along the preserved peripheral and costal plates (e.g., Fig. 5K, L, W'). 
Peripheral plates 1-3, together with the nuchal, make up the anterior opening of the shell. Peripheral 1 is heptagonal, while the peripheral 2 is subtriangular. Peripheral 1 displays a moderately developed spike at about the middle of the anterior edge. The presence of protrusions on the remaining peripherals (i.e., 2 and 3) cannot be evaluated. Peripheral 5 (Pal. 1338: Fig. 5A', B'), which is the only preserved plate involved in the shell bridge, is rectangular and rather flat, unlike posterior peripherals. Pal. 1338 displays a very weak longitudinal lateral ridge that is placed slightly above of the marginoabdominal sulcus. Peripherals 7-11 (Fig. 5C'-W'), together with the pygal plate (Fig. $5 \mathrm{H}-\mathrm{J}$ ), form the posterior opening of the shell. An elongated and subvertical scar of the dorsal projection of the hypoplastron is discernible in peripheral 7 internally (Fig. 5E', F'). As a rule, the peripherals 8-10 in Testudo are rectangular with dorsal surfaces slightly concave, whereas in Ptychogaster, they are rather subrectangular and the dorsal concavity is well-developed. Peripheral 11 hosts the lateral edge of the supracaudal scute (Fig. 5S'-W'). The marginal scute 1 is trapezoidal, whereas the remaining posterior marginals are either subsquare or subrectangular (Fig. 5A-D, S-V, W'). Based on two nuchal plates (Pal. 1319-21), two peripherals 1 (Pal. 1332-33) and three costals 1 (Pal. 1326-28), the triple junction amongst the pleural 1 , vertebral 1 , and marginal 1 is located outside the nuchal plate. Noticeably, the posterior border of the marginal 5 (Pal. 1338; Fig. 5A', B') is parallel (i.e., instead of oblique) relative to those anteroposterior edges of the peripheral 5.

A partial epiplastron, together with the hyoplastron (Fig. 6A-F, O-R), forms the anterior plastral lobe, which is rather trapezoidal (Fig. 6I'). Despite not being entirely preserved, the epiplastral dorsal pad seems rectangular and longer than wide. It is moderately developed posteroventrally and overhangs it slightly. Consequently, a small gular pocket is present (Fig. 6A-C). The gular scutes are triangular, with slightly sinuous lateral margins, and form an angle of less than $45^{\circ}$ relative to the sagittal axis (Fig. 6B-D).

The three available entoplastra (Pal. 1352-54: Fig. 6G-N) are hexagonal both ventrally and viscerally. They are partially covered by the gular scutes, which generally extend up to the middle of the entoplastron. The ventral surface of the epiplastra, covered by the gular scutes, is not in relief. In all specimens, the gular scutes are not crossed by the humeropectoral sulcus transversally (Fig. 6H, I, K, L).

Pal. 1351B is the best preserved hyoplastron (Fig. 6O-R), which hosts entirely both the humeropectoral and pectoroabdominal scutes: the former is nearly straight and obliquely oriented relative to the sagittal plane (i.e., only slightly sinuous: Fig. 6R), while the latter is curved and transversally oriented relative to the sagittal plane (Fig. 6R, $\mathrm{V})$. The preserved portion of the humeral scute indicates that this was trapezoidal. The abdominal seems to be the largest scute of the plastron. Moreover, its medial sector is slightly oblique (Fig. 6Y-Z). The hypo-xiphiplastral suture is roughly straight and well developed, which means that a plastral hinge is absent. The xiphiplastron is trapezoidal and its ventral side is very flat and crossed by the femoroanal sulcus (Fig. 6A'-C'). It is noteworthy that the distinct notch in their lateral margins, between the anal and femoral scutes, is missing (Fig. 6A', C'). The femoral is trapezoidal and much longer medially than the anal scutes, which are subrectangular and wider than long. The femoroanal sulcus is slightly sinuous and obliquely oriented relative to the sagittal plane. The anal notch is wider than long, and its visceral area covered by the anal scutes is variable, from moderately (Pal. 1361: Fig. 6A', B') to well developed (Pal. 1362: Fig. 6E', F').

\section{REMARKS}

The genus Testudo s.l. is a clade with five extant and multiple extinct species of terrestrial tortoises of western Palearctic distribution (Lapparent de Broin et al. 2006a, b; Fritz \& Bininda-Emonds 2007; Corsini et al. 2014; Delfino et al. 2012; Luján et al. 2016). Despite that, in the past, three extant genus-group taxa were distinguished as genera (see e.g., Turtle Taxonomy Working Group 2014), currently, the use of a single genus (Testudo s.l.) and three subgenera (Testudo, Agrionemys and Chersine) is being better accepted (see Luján et al. 2016; Graciá et al. 2017; Turtle Taxonomy Working Group 2017). Among extinct taxa, the taxonomy of Testudo s.l. also included the distinction of the extinct genus Paleotestudo Lapparent de Broin, 2000. Although the latter has not been the object of an exhaustive review, results presented by Luján et al. (2016) clearly pointed out that Paleotestudo is a junior subjective synonym of subgenus Chersine.

Regarding the species Testudo kalksburgensis Toula, 1896, it was originally described by Toula (1896) based on one specimen from Kalksburg, Vienna: a partial shell currently housed at the IGUW. At the beginning of the twentieth century, new fragmentary material, coming from the late Miocene locality of Au am Leithaberge, was referred to T. kalksburgensis by Siebenrock (1914). Shortly after, Staesche (1931) also erected Testudo kalksburgensis var. steinheimensis based on various specimens from the middle Miocene (MN7) locality of Steinheim (Germany). Although T. kalksburgensis was considered a junior subjective synonym of T. antiqua Bronn, 1831 by Glaessner (1933), subsequently Młynarski (1976) resurrected the species once again. Indeed, the validity of T. kalksburgensis was also confirmed by latter studies (see Młynarski 1980; Bachmayer \& Młynarski 1981; Schleich 1981; Gemel \& Rauscher 2000; Gemel 2002; Danilov et al. 2012; Luján et al. 2016; Březina et al. 2021).

FIG. 5. - Carapace remains of Testudo (Testudo) cf. kalksburgensis from Mokrá-Quarry localities: A-D, Pal. 1320 (nuchal); A, B, dorsal; C, D, visceral; E, Pal. 1322 (neural 4) in dorsal; F, Pal. 1323 (neural 6) in dorsal; G, Pal. 1350 (neural 7) in dorsal; H-J, Pal. 1325 (pygal); H, external; I, J, internal; K, L, Pal. 1326 (costal 1) in dorsal; M, N, Pal. 1329 (costal 2) in dorsal; O, P, Pal. 1330 (costal 3) in dorsal; Q, R, Pal. 1331 (costal 6) in dorsal; S-V, Pal. 1333 (peripheral 1); S, T, external; U, V, internal; W-Z, Pal. 1334 (peripheral 2); W, X, external; Y, Z, internal; A', B', Pal. 1338 (peripheral 5) in external; C'-F', Pal. 1340 (peripheral 7); C', D', exter- 

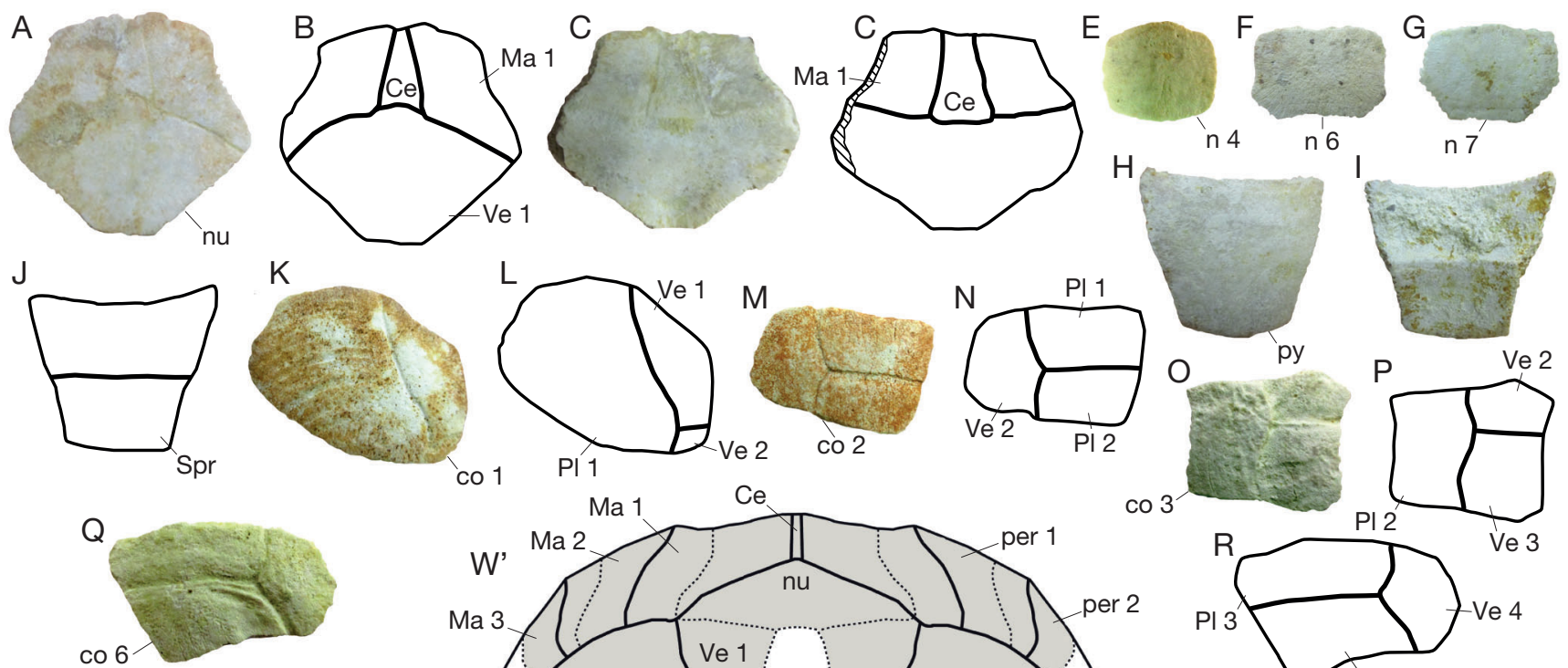

$\mathrm{S}$
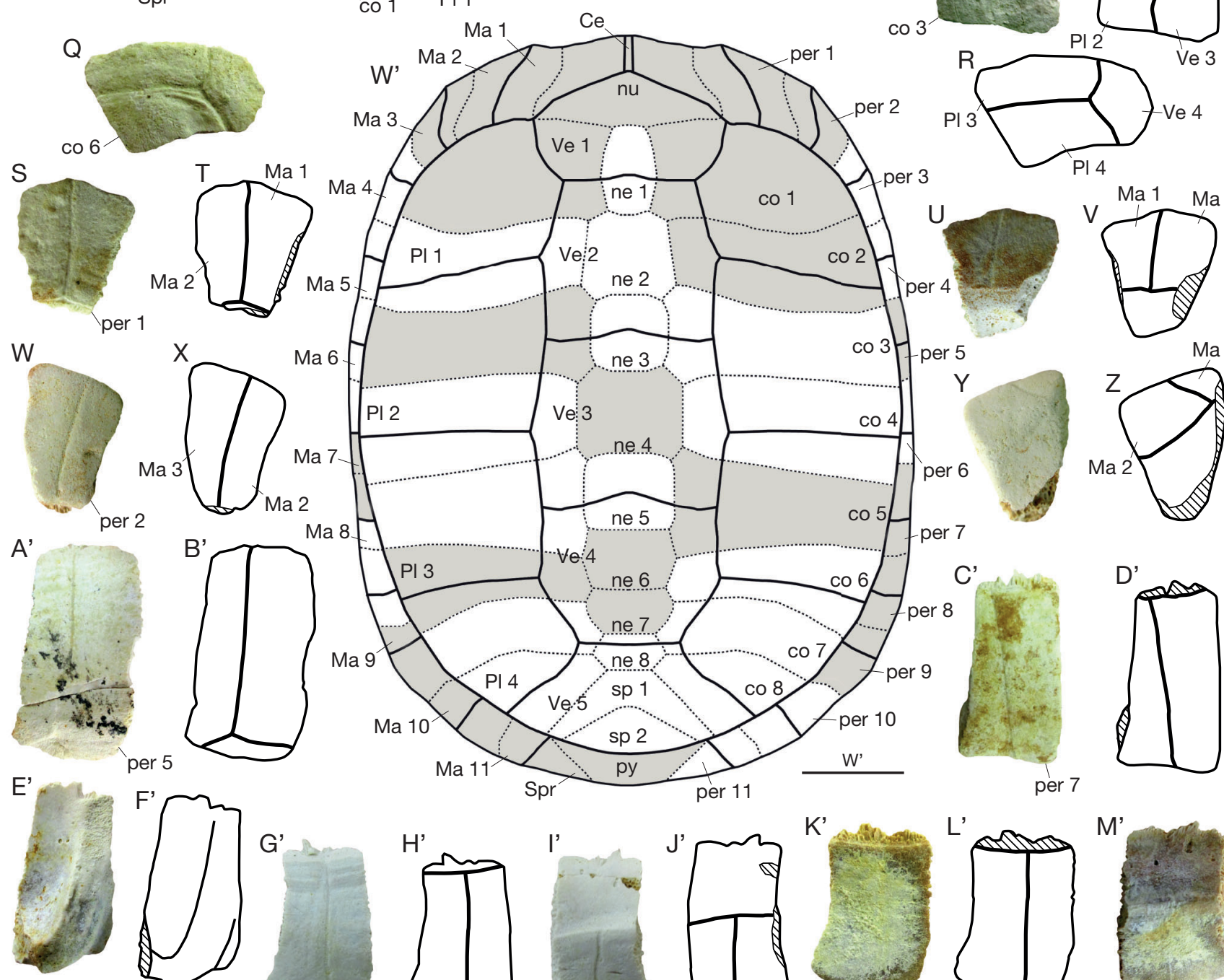

per 5

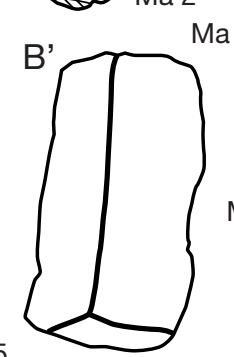
Ma 8
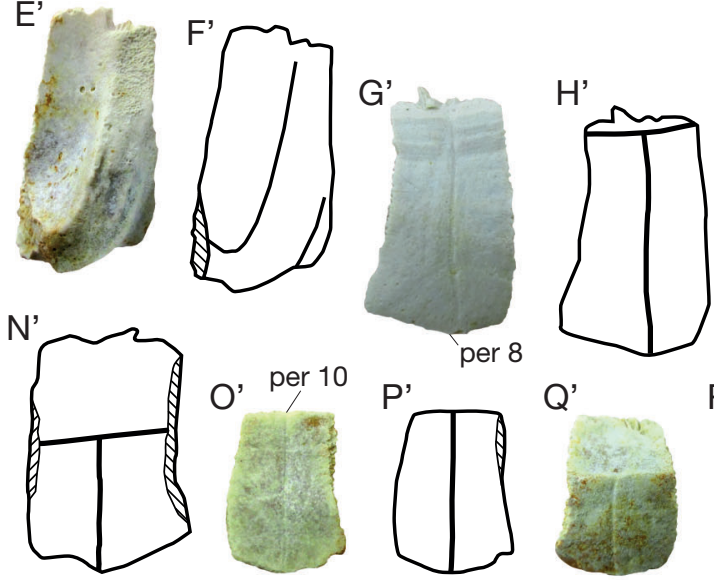

Q'
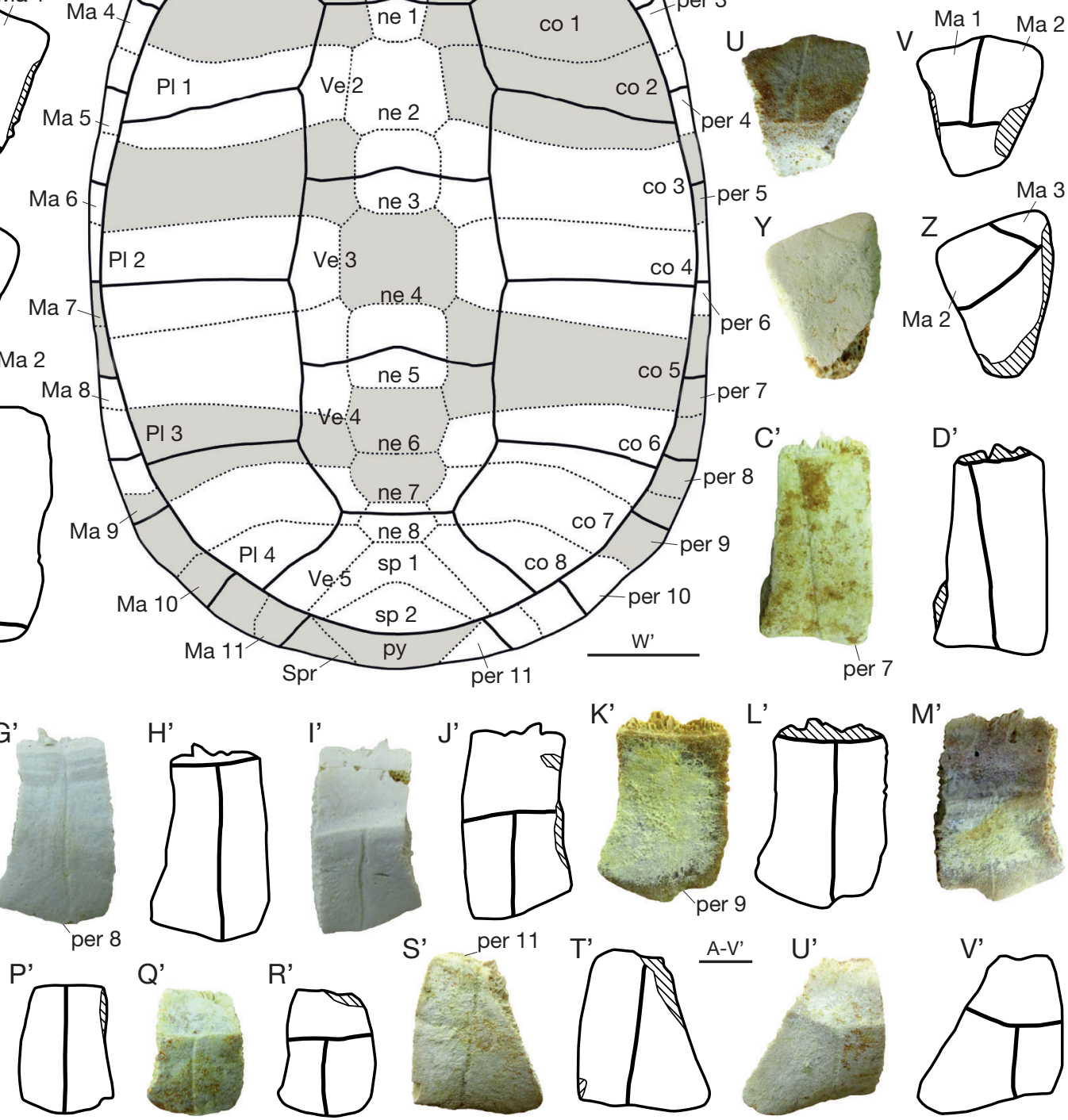

per 7
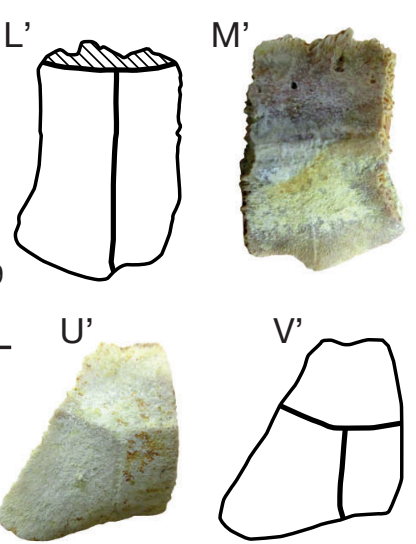

nal; E', F', internal, G'-J', Pal. 1341 (peripheral 8); G', H', external; l', J', internal; K'-N', Pal. 1343 (peripheral 9); K', L', external; M', N', internal; O'-R', Pal. 1345 (peripheral 10); O', P', external; Q', R', internal; S'-V', Pal. 1348 (peripheral 11); S', T', external; U', V', internal views; W', reconstruction of carapace Thick lines correspond to scute sulci, dotted lines denote plate sutures, and oblique lines indicate missing plate portions. Abbreviations: Ce, cervical; co, costal; Ma, marginal; ne, neural; nu, nuchal; per, peripheral; PI, pleural; py, pygal; sp, suprapygal; Spr, supracaudal; Ve, vertebral. Scale bars: A-V', 1 cm; W', 2.5 cm. 

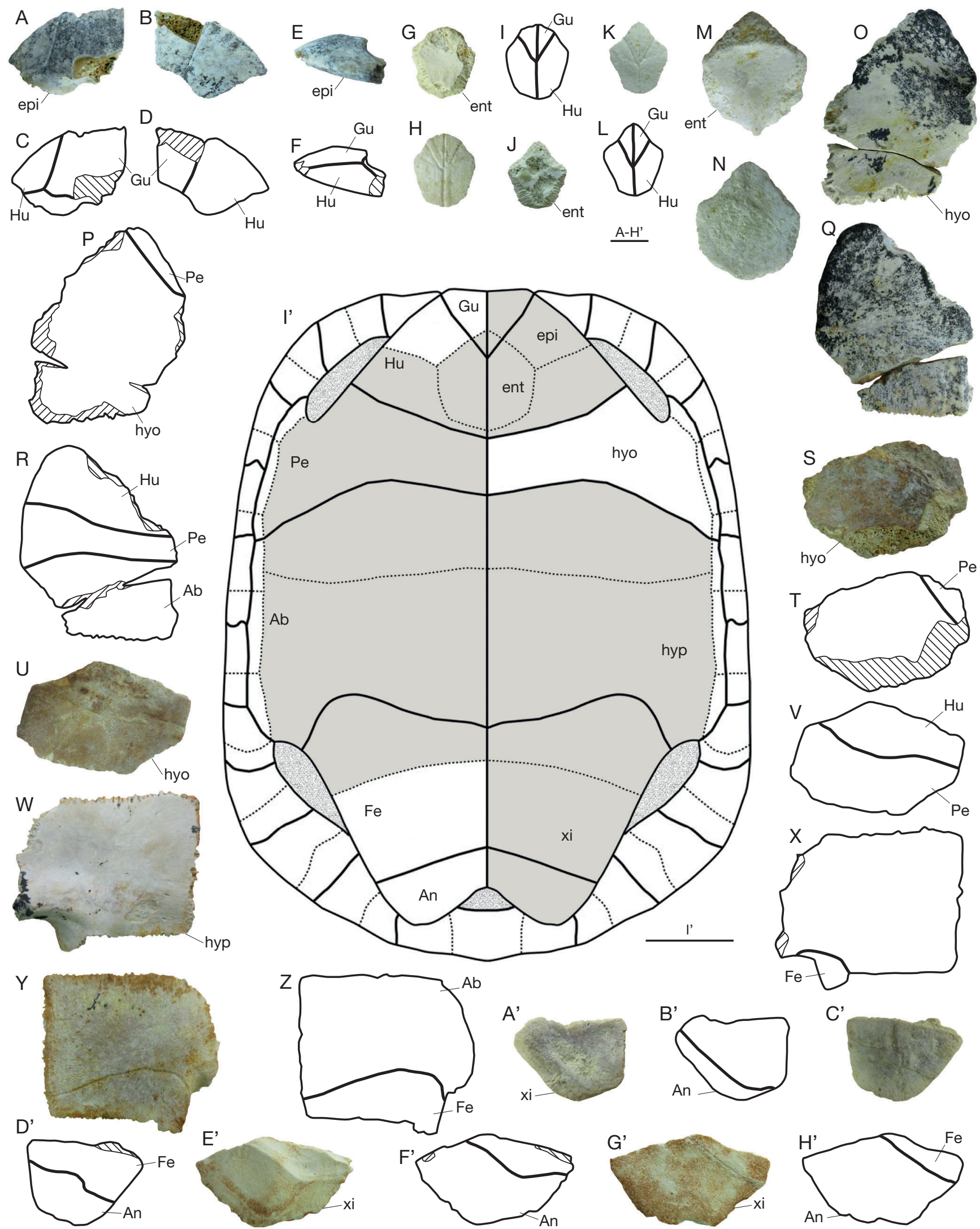

FIG. 6. - Plastral remains of Testudo (Testudo) cf. kalksburgensis: A-D', from Mokrá-Quarry localities; A-F, Pal. 1351A (left epiplastron); A, C, visceral; B, D, ventral; E, F, left lateral; G-I, Pal 1354 (entoplatron); G, visceral; H, I, ventral; J-L, Pal. 1353 (entoplatron); J, visceral; K, L, ventral; M, N, Pal. 1352 (entoplatron); M, visceral; N, ventral; O-R, Pal. 1351B (hyoplastron); O, P, visceral; Q, R, ventral; S-V, Pal. 1355 (hyoplastron); S, T, visceral; U, V, ventral; W-Z, Pal. 1356 (hypoplastron); W, X, visceral; Y, Z, ventral; A'-D', Pal. 1360 (xiphiplastron); A', B', visceral; C', D', ventral; E'-H', Pal. 1361 (xiphiplastron); E', F', visceral; G', H', ventral views; I', reconstruction of plastron. Thick lines correspond to scute sulci, dotted lines denote plate sutures, and oblique lines indicate missing plate portions. Abbreviations: Ab, abdominal; An, anal; ent, entoplastron; epi, epiplastron; hyo, hyoplastron; hyp, hypoplastron; Fe, femoral; Gu, gular; Hu, humeral; Pe, pectoral; xi, xiphiplastron. Scale bars: A-H', $1 \mathrm{~cm}$; I', $2.5 \mathrm{~cm}$. 


\section{DISCUSSION}

TAXONOMIC ATTRIBUTION OF THE DESCRIBED REMAINS Ptychogaster (Ptychogaster) sp.: Almost half of the fossil turtle material from Mokrá-Quarry can be referred to the genus Ptychogaster. This is the case, not only for the material coming from the localities of $1 / 2001$ and $2 / 2003$, but also from the newly recovered ones, from both the western (TC/2001 and MWQ4/2018), and central part (3/2005). Ptychogasterid remains of both localities (1/2001 and 2/2003) were originally referred to extant genus Chrysemys by Ivanov $\&$ Musil (2004), or alternatively to family Emydidae subsequently (see Ivanov et al. 2006). In neither of these two works, did the authors provide a discussion, nor figured these shell remains, and therefore this attribution cannot be justified. However, the geoemydid material described here can be referred to the genus Ptychogaster (Ptychogasteridae: Ptychogasterinae) on the basis of the well developed pair of internal thickenings on the ventral surface of nuchal, a completely ligamentous union between hypoplastron and peripherals, and the presence of a hinge between hyo- and hypoplastron at the level of the peripheral 6. Moreover, the most complete ptychogasterid remains show longer anterior peripherals, irregular neural series formed mainly by octagonal and hexagonal plates with short sides in front, and a nuchal that is longer than wide. The latter features characterize the subgenus Ptychogaster, and further discounts an alternative attribution to the subgenus Temmnoclemmys (Luján et al. 2014). Given that the most diagnostic shell part in ptychogasterids is missing (i.e., the dorsal epiplastral lip), the remains from Mokrá-Quarry are too scarce to provide a taxonomic assignment at the species level. In any case, the ptychogasterid material presented here enables to confirm that Ptychogaster was also present in the South Moravian Region during the early Miocene (MN4). To date, the ptychogasterids had only been reported in Ohře/Eger Graben (NW Czechia), mainly on the basis of described material from Dolnice site (Cheb Basin: Młynarski \& Roček 1985). This agrees with the range of subgenus Ptychogaster in Czechia, where it is already recorded, but has yet to be studied in detail, including the following early Miocene (MN3) localities: Ahníkov/Merkur-North Mine, Břeštany, Most/Brüx, Tuchorice and Želeč (Laube 1900, 1901; Schlosser 1910; Liebus 1930; Fejfar \& Kvaček 1993; Kvaček et al. 2004: Böhme \& Ilg 2003; Schäfer 2013; Ivanov 2015; BonillaSalomón et al. 2021).

\section{Testudinidae indet.}

Large-sized testudinid material recovered from MWQ4/2018 is similar in size to that of the genus Titanochelon (PérezGarcía \& Vlachos 2014). Particularly, the morphology of preserved postcranial bones (i.e., scapula and tibia), along with the shell plate, resembles that of the middle Miocene (MN6) species Ti. vitodurana from Switzerland. However, specimens from MWQ4/2018 cannot be referred to genus Titanochelon on the basis of size, as material from Ahníkov/ Merkur Mine (Ohře/Eger Graben, NW Czechia) suggests that, apart from Titanochelon, a second giant tortoise inhabited Central Europe during the early Miocene (Luján pers. observ.). In any case, the material presented here is the second report of giant testudinids in Czechia (see Březina et al. 2019), and certainly, more material will be required to clarify the taxonomy of this finding.

\section{Testudo (Chersine) cf. kalksburgensis}

The second most abundant turtle material from MokráQuarry is a small testudinid, ascribed to genus Testudo. It belongs to subgenus Chersine (see Luján et al. 2016), which is characterized by: a trapezoidal (instead of rounded) anterior plastral lobe; in the posterior border of marginal scute 5 being parallel (instead of oblique) to those of peripheral plate 5; and the absence of a plastral hinge, along with a not elevated shell bridge. Among the species of the subgenus Chersine from Central Europe, the material described here most closely resembles $T$. (Ch.) kalksburgensis in the morphology of the epiplastral dorsal pad (i.e., moderately developed posteroventrally and overhanging it slightly), and by the presence of a small gular pocket (Luján et al. 2016). Due to incomplete preservation of the anterior edge of epiplastron (i.e., protruding in T. steinheimensis) and the absence of the neural 1 (i.e., with a marked posterior constriction in $T$. catalaunica), we cannot conclude that specimens from Mokrá-Quarry belong to $T$. (Ch.) kalksburgensis.

\section{Palaeoecological ReCONSTRUCTION}

Mokrá-Quarry localities represent one of the most diverse and well-documented early Miocene (late EggenburgianOttnangian) vertebrate assemblages in Central Europe (Ivanov \& Musil 2004; Ivanov 2008; Ivanov et al. 2006, $2018,2020)$. To date, 40 ectothermic taxa belonging to amphibians (13 taxa) and reptiles (three turtle taxa and 24 squamate taxa) have been recorded. Although the number of turtle remains recovered from Mokrá-Quarry is relatively high (over 100 shell plates), it shows a rather low diversity, including two tortoises (of which one is gigantic) and one geoemydid. Turtle fauna is consistent with three different palaeoenvironments, which are further supported by the faunal assemblages of mammals, amphibians, and the rest of reptiles (i.e., squamates). The members of the genus Ptychogaster were classified as aquatic turtles by Reinach (1900), which means they spend most of their lives in the water bodies, only venturing ashore to lay their eggs or to thermoregulate their bodies. Conversely, De Stefano (1903) proposed that ptychogasterids were actually semi-terrestrial, which would imply that they will spend a significant amount of time on land near bodies of water, or even close to the shoreline. He justified this hypothesis mainly on the proportions and robustness of its forelimbs. Subsequent authors (e.g., Młynarski 1976; Gemel 2002) also supported this lifestyle, since they had a high vaulted carapace: nevertheless, they did not discard that some species could be semiaquatic. As a rule, all semiaquatic and semi-terrestrial turtles (i.e., Emydoidea, Kinosternon, Terrapene and some species of Rhi- 
noclemmys) display a relatively vaulted shell (Marmi \& Luján 2012). However, all extant turtles with a domed shell are not semi-terrestrial, and therefore this feature is not useful to infer the lifestyle (e.g., Joyce \& Gauthier; Benson et al. 2011). Moreover, different species within the same genus may have different natural histories and, as a result, some of them have a greater tendency to travel overland (Steen et al. 2012). Despite the fact that we cannot confirm all ptychogasterid species to have been semi-terrestrial turtles (not within the scope of this paper), the Ptychogaster material from Mokrá-Quarry is consistent with the nearby presence of freshwater (Alba et al. 2018; Casanovas-Vilar et al. 2018). According to the palaeoreconstruction conducted by Ivanov et al. $(2018,2020)$ based on amphibian and reptiles, ptychogasterids from Mokrá-Quarry would have lived in the surroundings of damp, or even marsh-like habitats.

Two tortoise taxa (Testudinidae indet. and Testudo cf. kalksburgensis), adapted to dry and open environments have been found in Mokrá-Quarry. The giant tortoise, recovered only in MWQ4/2018, had a large body and would had needed some kind of vegetation cover or caves (i.e., shaded places) in order to cool down their body temperature (Schleich 1988; Böhme 2008). In any case, the giant tortoises would have inhabited areas near to open forest environments. In turn, the small tortoise Testudo cf. kalksburgensis would have preferred an even more open and dryer environment, such as a steppe (e.g., Baruš et al. 1992; Čerňanský et al. 2012).

Therefore, Mokrá-Quarry localities should be interpreted as a karst landscape surrounded by open forest environments and steppe, as shown by the abundant remains of amphibians and reptiles (Ivanov 2008; Ivanov et al. 2018; 2020). Some small mammal taxa recovered from both localities (1/2001 and 2/2003) have been associated with open environment conditions and warm weather, including the cricetodontids genera Democricetodon and Megacricetodon, and the sciurid Palaeosciurus (Sabol et al. 2007). The record of Melissiodon also suggests wooden areas and somewhat more humid conditions (Jovells-Vaqué \& Casanovas-Vilar 2018). With regards to the large mammal association, they consist of cervids and one suid, which confirm forested and swampy environments (Rössner 2004). Despite the similar palaeoecology of both fissures (1/2001 and 2/2003), however herpetofauna of $2 / 2003$ points to a slightly more humid palaeoenvironment, supported by the abundance of amphibians such as Triturus, Chioglossa and Mertensiella as well (Ivanov 2008; Ivanov et al. 2018). Additionally, it is also reinforced by the presence of some fossorial squamates (Amphisbaenia indet.) and micromammals such as Ligerimys sp., as well as the more abundant remains of Galerix and other erinaceids (Daams \& Freudenthal 1988; Van der Meulen \& Daams 1992; Ziegler 1999). Furthermore, several publications dealing with the micro- and macromammals from Mokrá-Quarry localities are in progress (I. Bonilla-Salomón, pers. comm.), which will shed light on our understanding of the palaeoclimatic conditions on each fissure, and more generally during Miocene Climatic Optimum in Central Europe.

\section{CONCLUSIONS}

Turtle remains from the early Miocene (MN4) localities of Mokrá-Quarry (Czech Republic) are herein described and attributed to three taxa: Ptychogaster (Ptychogaster) sp.; Testudinidae indet.; and Testudo (Chersine) cf. kalksburgensis. Large testudinids were recovered in MWQ4/2018 only, which is likely attributable to a fossil record bias. Both small testudinid and ptychogasterid remains represent the first fossil record from the South Moravian Region. The turtle assemblage recovered from Mokrá-Quarry is similar to those from the Vienna Basin and the North Alpine Foreland Basin. Finally, the presence of two terrestrial tortoises and one semi-terrestrial geoemydid is entirely consistent with the palaeoenvironmental reconstruction of Mokrá-Quarry localities, as a karst landscape surrounded by open forest and steppe.

\section{Acknowledgements}

The research reported in this work was funded by the Spanish Agencia Estatal de Investigación - European Regional Development Fund of the European Union (ÀHL: CGL201676431-P, CGL2017-82654-P and AEI/FEDER EU), the Generalitat de Catalunya (ÀHL: CERCA Programme), the VEGA Scientific Agency (AČ: 1/0209/18; IBS: 1/0164/19), the APVV grant agency of the Slovak Republic (IBS: APVV16-0121), the Ministry of Culture of the Czech Republic (JB: DKRVO, MK000094862), the SPECIFIC research project at the Faculty of Science at Masaryk University, Brno (MI, JB: MUNI/A/0944/2019), and from the Operational Programme Research, Development and Education - Project “Postdoc@MUNI” (No. CZ.02.2.69/0.0/0.0/16_027/000 8360). ÀHL acknowledges a research visit to the University of Comenius in Bratislava, Slovakia (National Scholarship Programme of the Slovak Republic for the support of mobility of researchers, Autumn Call 2017). We thank the editors M. Augé, G. Metais and J.-S. Steyer for preparing a special volume tribute to the memory of Jean-Claude Rage. Finally, we are grateful to Walter Joyce and to an anonymous reviewer for many helpful comments and suggestions that helped us to improve a previous version of this paper.

\section{REFERENCES}

Alba D. M., Carmona R., Bolet A., Robles J. M., CasanovasVilar I., Furió M., Sanisidro Ó., Rifà E., Balaguer J., Checa L., LuJÁN À. H., TOMÀS M. \& MOYÀ-SOlÀ S. 2010. - Intervención paleontológica en la Autovía Orbital de Barcelona B-40, tramo Olesa de Montserrat-Viladecavalls: Resultados preliminaries. Cidaris 30: 51-59 (in Spanish with English summary).

Alba D. M., Carmona R., Bertó Mengual J. V., CasanovasVilar I., Furió M., Garcés M., Galindo J. \& Luján, À. H. 2011. - Intervenció paleontològica a l'Ecoparc de Can Mata (els Hostalets de Pierola, conca del Vallès-Penedès). Tribuna d'Arqueologia 2011: 115-130 (in Catalan with English summary).

Alba D. M., Casanovas-Vilar I., Furió M., García-Paredes I., Angelone C., Jovells-Vaqué S., Luján À. H., Almécija S. \& MOYȦ-SOLÀ S. 2018. — Can Pallars i Llobateres: A new 
hominoid-bearing locality from the late Miocene of the VallèsPenedès Basin (NE Iberian Peninsula). Journal of Human Evolution 121: 193-203. https://doi.org/10.1016/j.jhevol.2018.04.008

AufFenberG W. 1974. - Checklist of fossil land tortoises (Testudinidae). Bulletin of the Florida State Museum Biological Sciences 18 (3): 121-251. https://ufdc.ufl.edu/UF00027859/00001

BACHMAYER M. F. \& MŁYNARSKI M. 1981. - Testudo kalksburgensis Toula, 1896, eine valide Schildkrötenart aus den miozänen Strandbildungen von Kalksburg bei Wien. Sitzungsberichte Osterreichische Akademie der Wissenschaften, Mathematisch. Naturwissenschaftliche Klasse 190: 111-119.

Baruš V., Oliva O., Kminiak M., Král B., Opatrný E., Rehák I., Roth P., ŠPINAR Z. \& VojtKOV L. 1992. — Fauna ČSFR: Plazy Reptilia. Academia, Prague, 222 p.

Benson R. B., Domokos G., VÁrkonyi P. L. \& Reisz R. R. 2011. - Shell geometry and habitat determination in extinct and extant turtles (Reptilia: Testudinata). Paleobiology 37 (4): 547-562. https://doi.org/10.1666/10052.1

BÖHME M. \& IlG A. 2003. - fosFARbase, http://www.wahrestaerke.com (last consultation on 2019-04-01).

BöHME M. 2008. - Ectothermic vertebrates (Teleostei, Allocaudata, Urodela, Anura, Testudines, Choristodera, Crocodylia, Squamata) from the Upper Oligocene of Oberleichtersbach (Northern Bavaria, Germany). Courier Forschungsinstitute Senckenberg 260: 161-183.

Bonilla-Salomón I., Čermák S., luján À. H., HoráČeK I., IVANOV M. \& SABOL M. 2021. - Early Miocene small mammals from MWQ1/2001 Turtle Joint (Mokra-Quarry, South Moravia, Czech Republic): biostratigraphical and palaeoecological considerations. Bulletin of Geosciences 96 (1): 99-122. https:// doi.org/10.3140/bull.geosci.1801

BOURGAT R. \& BOUR R. 1983. - La Tortue géante de Perpignan: Cheirogaster perpiniana (Depéret, 1885). Bulletin de la Société agricole, scientifique et litteraire des Pyrennées-Orientales 91: 167-177.

Březina J., Luján À. H., CALÁbKOVÁ G. \& IVANOV M. 2019. Revize historického nálezu obří želvy z brněnských písků (střední miocén, spodní baden). Acta Musei Moraviae, Scientiae Geologicae 104 (1): 113-128 (in Czech).

BŘezina J., Alba D. M., Ivanov M., HanáČeK M. \& Luján À. H. 2021. - A middle Miocene vertebrate assemblage from the Czech part of the Vienna Basin: Implications for the paleoenvironments of the Central Paratethys. Palaeogeography, Palaeoclimatology, Palaeoecology 575: 110473. https://doi.org/10.1016/j. palaeo.2021.110473

BRZOBOHATÝ R. 1997. — Paleobatymetrie spodního badenu karpatské předhlubně na Moravě z pohledu otolitových faun, in HLADILOvá S. (ed.), Dynamika vztahỉ marinního a kontinentálního prostredí. Masaryk University, Brno: 37-45 (in Czech).

BrZOBOHATÝ R., KudĚLÁSEK V. \& NeHYBA S. 2000. — Nejspodnější baden (střední miocén) v okolí Mokré u Brna. Geologické výzkumy na Moravě a ve Slezsku v roce 1997: 58-60 (in Czech). https:// journals.muni.cz/gvms/article/view/5099

Carmona R., Alba D. M., Casanovas-Vilar I., Furió M., Garcés M., Bertó Mengual J. V., Galindo J. \& Luján À. H. 2011. Intervención paleontológica en la serie del Mioceno Superior del Ecoparc de Can Mata (cuenca del Vallès-Penedès, NE de la península Ibérica), in Pérez-García A., Gascó F., Gasulla J. M. \& EsCASO F. (eds), Viajando a mundos pretéritos. Ayuntamineto de Morella, Morella: 65-74 (in Spanish with English summary).

Casanovas-Vilar I., Sanisidro Ó., Madurell-Malapeira J., DeMiguel D., Jovells-Vaqué S., Luján À. H., Furió M. \& Robles J. M. 2018. - Els jaciments de vertebrats del Miocè inferior de Gelida. Quaderns Gelidencs d'Història i Societat 4: 1-44 (in Catalan).

ČERŇANSKÝ A., TÓTH C. \& ŠURKA J. 2012. — Nálezy krokodíla a korytnačiek zo spodného miocénu lokality Baňa Dolina vo Vel'kom Krtíši (Slovensko). Acta Geologica Slovaca 4 (2): 113-123 (in Slovak with English summary).
Claude J. 2006. - Convergence induced by plastral kinesis and phylogenetic constraints in Testudinoidea: a geometric morphometric assessment. Russia Journal of Herpetology 13 (Suppl.): 34-55.

Claude J. \& Tong H. 2004. - Early Eocene testudinoid turtles from Saint-Papoul, France, with comments on the early evolution of modern Testudinoidea. Oryctos 5: 3-45.

CORSINI J. A., BÖHME M. \& JoYCE W. G. 2014. - Reappraisal of Testudo antiqua (Testudines, Testudinidae) from the Miocene of Hohenhöwen, Germany. Journal of Paleontology 88 (5): 948-966. https://doi.org/10.1017/S0022336000057590

ČTyrokÝ P., Kantorová V., OndrejíčKová A., Strauch F. \& VASS D. 1973. - Faziostratotypen der Rzehakia (Oncophora) Formation, in PAPP A., RÖGL F. \& SENEŠ J. (eds), Chronostratigraphie und Neostratotypen Miozän der zentralen Paratethys. Band III M2 Ottnangien. Die Innviertler, Salgótarjáner, Bántapusztaer Schichten gruppeund die Rzehakia Formation. Slowakische Akademie der Wissenschaften, Bratislava: 244-265.

DaAms R. \& Freudenthal M. 1988. - Synopsis of the DutchSpanish collaboration program in the Aragonian type area, $1975-$ 1986. Scripta Geologica, special issue 1: 3-18.

DANILOV I. G., ČERŇANSKÝ A., SYROMYATNIKOVA E. V. \& JONIAK P. 2012. - Fossil turtles of Slovakia: new material and a review of the previous record. Amphibia-Reptilia 33 (3-4): 423-442. https://doi.org/10.1163/15685381-00002846

DELFinO M., LujÁN À. H., CARMONA R. \& Alba D. M. 2012. — Revision of the extinct Pleistocene tortoise Testudo lunellensis Almera and Bofill, 1903 from Cova de Gràcia (Barcelona, Spain). Amphibia-Reptilia 33 (2): 215-225. https://doi.org/10.1163/156853812X636466

De Stefano G. 1903. - Ptychogaster miocenici della Francia conservati nel Museo di Storia naturale di Parigi. Palaeontografica Italica 9: 61-94.

FejFar O. 1974. - Die Eomyiden und Cricetiden (Rodentia, Mammalia) des Miozäns der Tschechoslowakei. Palaeontographica Abteilung A 146: 100-180.

FEJFAR O. 1990. - The Neogene vertebrate paleontology sites of Czechoslovakia: A contribution to the Neogene terrestric biostratigraphy of Europe based on rodents, in LINDSAY E. H., FAHLBUSCH V. \& Mein P. (eds), European Neogene Mammal Chronology. Plenum Press, New York: 211-236. https://doi.org/10.1007/978$1-4899-2513-8 \quad 15$

Fejfar O. \& KVAČEKZ. 1993. - Excursion Nr. 3 - Tertiary basins in Northwest Bohemia. Paläontologische Gesellschaft 63: 16-18.

Fritz U. \& Bininda-Emonds O. R. P. 2007. - When genes meet nomenclature: Tortoise phylogeny and the shifting generic concepts of Testudo and Geochelone. Zoology 110 (4): 298-307. https://doi.org/10.1016/j.zool.2007.02.003

GEMEL R. 2002. - Weitere Schildkrötenreste aus dem Karpatium des Korneuburger Beckens (Untermiozän; Niederösterreich). Beitrage zur Palaeontologie 27: 373-393.

GEMEL R. \& RAUSCHER K. 2000. — Fossile Schildkröten aus Österreich (Reptilia, Testudiens. Stapfia 69: 63-86.

Graciá E. V. A., Vargas-Ramírez M., Delfino M., Anadón J. D., Giménez A., Fahd S., Corti C., Jdeidi T. B. \& Fritz U. 2017. - Expansion after expansion: dissecting the phylogeography of the widely distributed spur-thighed tortoise, Testudo graeca (Testudines: Testudinidae). Biological Journal of the Linnean Society 121 (3): 641-654. https://doi.org/10.1093/biolinnean/blx007

GLAESSNER M. F. 1933. - Die Tertiär schildkröten Niederösterreichs. Neues Jahrbuch für Mineralogie, Geologie, und Paläontologie, Abteilung B 69: 353-387.

Hervet S. 2004a. - Systématique du groupe "Palaeochelys sensu lato-Mauremys» (Chelonii, Testudinoidea) du Tertiaire d'Europe occidentale: principaux résultats. Annales de Paléontologie 90 (1): 13-78. https://doi.org/10.1016/j.annPal.2003.12.002

Hervet S. 2004b. - A new genus of 'Ptychogasteridae' (Chelonii, Testudinoidea) from the Geiseltal (Lutetian of Germany). Comptes Rendus Palevol3 (2): 125-132. https://doi.org/10.1016/j. crpv.2004.01.001 
Hervet S. 2006. - The oldest European ptychogasterid turtle (Testudinoidea) from the Lowermost Eocene amber locality of le Quesnoy (France, Ypresian, MP7). Journal of Vertebrate Paleontology 26 (4): 839-848. https://doi.org/fsgxx4

Hladil J., Bernardová E., Brunnerová Z., Brzobohatý R., Čekan V., Dvořák J., Eliáš M., Friáková O., Havlíček P., Kalvoda J., Klečák J., Machatková B., Maštera L., Mittrenga P., Otava J., Přichystal A., Rejl, L. \& RƯŽIČKA M. 1987. - Vysvétlivky kzákladní geologické mapè České republiky 1:25.000, 24-413 Mokrá-Horákov. Archive of the Czech Geological Survey. Prague, Czchia, 100 p. (in Czech; unpublished).

itescu Y., Karraker N. E., Raia P., Pritchard P. C. \& Meiri S. 2014. - Is the island rule general? Turtles disagree. Global Ecology and Biogeography 23 (6): 689-700. https://doi.org/10.1111/ geb. 12149

Ivanov M. 2008. - Early Miocene amphibians (Caudata, Salientia) from the Mokrá-Western Quarry (Czech Republic) with comments on the evolution of early Miocene amphibian assemblages in Central Europe. Geobios 41 (4): 465-492. https:// doi.org/10.1016/j.geobios.2007.11.004

IVANOV M. 2015. - Vývoj společenstev plazů ve střední Evropè v prüběhu kenozoika se zvlástním zrètelem k šupinatým (Squamata), in Moravec J. (ed.), Plazi-Reptilia. Academia, Prague: 15-46 (in Czech).

IvANOV M. \& Musil R. 2004. — Předběžné výsledky výzkumu neogenních obratlovců z lokality Mokrá-lom. Acta Musei Moraviae, Scientiae Geologicae 89: 223-236 (in Czech).

Ivanov M., Musil R. \& BrzobohatÝ R. 2006. - Terrestrial and marine faunas from the Miocene deposits of the Mokrá Plateau (Drahany Upland, Czech Republic) - Impact on palaeogeography. Beiträge zur Paläontologie 30: 223-239.

Ivanov M., Ruta M., Klembara J. \& BÖHMe M. 2018. — A new species of Varanus (Anguimorpha: Varanidae) from the early Miocene of the Czech Republic, and its relationships and palaeoecology. Journal of Systematic Palaeontology 16 (9): 767-797. https://doi.org/10.1080/14772019.2017.1355338

IVANOV M., ČERŇANSKÝ A., BONILLA-SALOMÓN I. \& LUJÁN À. H. 2020. - Early Miocene squamate assemblage from MokráWestern Quarry (Czech Republic) and its palaeobiogeographical and palaeoenvironmental implications. Geodiversitas 42 (20): 343-376. https://doi.org/10.5252/geodiversitas2020v42a20. http://geodiversitas.com/42/20

JOVELLS-VAQUÉ S. \& CASANOVAS-VILAR I. 2018. - A review of the genus Melissiodon (Cricetidae, Rodentia) in the Vallés-Penedès Basin (Catalonia). Journal of Vertebrate Paleontology 38 (5): e1520714. http://doi.org/10.1080/02724634.2018.1520714

JoyCE W. G. \& GAUTHIER J. A. 2004. - Palaeoecology of Triassic stem turtles sheds new light on turtle origins. Proceedings of the Royal Society of London, Series B: Biological Sciences 271 (1534): 1-5. https://doi.org/10.1098/rspb.2003.2523

KEAR B. P. 2010. - Evolution of gigantic tortoises from the Neogene of Europe. The Palaeontology Newsletter 73: 66-68.

KvaČeK Z., BÖHme M., Dvoř́́K Z., KOnZalová M., Mach K., PROKOP J. \& RAJCHL M. 2004. - Early Miocene freshwater and swamp ecosystems of the Most Basin (northern Bohemia) with particular reference to the Bílina Mine section. Journal of the Czech Geological Society 49 (1-2): 1-40.

LAPPARENT DE BROIN F. 2001. - The European turtle fauna from the Triassic to the Present. Dumerilia 4: 155-217.

Lapparent de Broin F., Bour R., Parham J. F. \& Perälä J. 2006a. - Eurotestudo, a new genus for the species Testudo hermanni Gmelin, 1789 (Chelonii, Testudinidae). Comptes Rendus Palevol 5 (6): 803-811. https://doi.org/10.1016/j. crpv.2006.03.002

Lapparent de Broin F., Bour R. \& Perälä J. 2006b. - Morphological definition of Eurotestudo (Testudinidae, Chelonii): First part. Annales de Paléontologie 92 (3): 255-304. https:// doi.org/10.1016/j.annpal.2006.07.001
Laube C. G. 1900. — Neue Schildkröten und Fische aus der böhmischen Braunkohlenformation. Abhandlungen des Deutschen Naturwissenschaftlich-Medizinischen Vereins für Böhmen "Lotos" 2: 37-56

Laube C. G. 1901. - Synopsis der Wirbeltierfauna der Böhmischen Braunkohlenformation. Abhandlungen des Deutschen Naturwissenschaftlich-Medizinischen Vereins für Böhmen "Lotos" 2: $1-80$.

Liebus A. 1930. - Neue Schildkrötenaus den Tertiären Süsswassertonen von Preschen bei Bilin in Böhmen. Rozpravy Státního geologického ústavu Ceskoslovenské Republiky 4: 1-57.

Loveridge A. \& Williams E. E. 1957. - Revision of the African tortoises and turtles of the suborder Cryptodira. Bulletin of the Museum of Comparative Zoology 115 (6): 163-557. https://www. biodiversitylibrary.org/part $/ 2475$

LujÁN À. H. 2015. - Les tortugues (Testudines) del Neogeni Quaternari de Catalunya (NE de la Peninsula Ibèrica). PhD dissertation, Universitat Autònoma de Barcelona, 417 p. (in Catalan with English summary; online published).

Luján À. H., Alba D. M., Fortuny J. \& Delfino M. 2010. Cranial remains of Cheirogaster Bergounioux 1935 (Testudines: Testudinidae) from the late Miocene of Ecoparc de Can Mata (Vallès-Penedès Basin, Catalonia, Spain). Cidaris 30: 163-168 (in Spanish with English summary).

Luján À. H., Delfino M., Casanovas-Vilar I. \& Alba D. M. 2014. - Taxonomy of subgenus Temnoclemmys Bergounioux, 1958 (Testudines: Geoemydidae: Ptychogasterinae) based on new material from the Vallès-Penedès Basin. Comptes Rendus Paleovol 13 (4): 277-295. https://doi.org/10.1016/j.crpv.2013.11.004

LujÁn À. H., Delfino M., Robles J. M. \& Alba D. M. 2016. A review of the Miocene tortoise Testudo catalaunica Bataller, 1926 and a revised phylogeny of extinct species of genus Testudo (Testudines: Testudinidae). Zoological Journal of the Linnean Society 178 (2): 312-342. https://doi.org/10.1111/zoj.12414

LujÁn À. H., IVAnov M., Fortuny J. \& SABOl M. 2017a. Fossil turtle remains from the Early Miocene (MN4) localities of Mokrá Quarry (Czech Republic) [Abstract], in YNHSM, $4^{\text {th }}$ Young Natural History Scientist Meeting. Paris, France, 87. Luján À. H., Alcover J. A., Ivanov M., Torres E. \& Alba, D. M. 2017b. - Revisión taxonómica de "Testudo" gymnesica Bate, 1914 (Testudines, Testudinidae) a partir de la descripción del material tipo de Menorca (Islas Baleares). Spanish Journal of Paleontology 32 (2): 261-278 (in Spanish with English summary). https://doi.org/10.7203/sjp.32.2.17043

MARMI J. \& LUJÁN À. H. 2012. - An overview of the threatened phylogenetic diversity of living testudines based on a review of the complex evolutionary history of turtles, in COSGROVE M. J. \& Roe S. A. (eds), Turtles: Anatomy, Ecology and Conservation. Nova Science Publishers, New York: 117-150.

Miklas-Tempfer P. M. 2002. - The Miocene Herpetofaunas of Grund (Caudata; Chelonii, Sauria, Serpentes) and Mühlbach am Manhartsberg (Chelonii, Sauria, Amphisbaenia, Serpentes), Lower Austria. Annalen des Naturhistorischen Museums in Wien 104A: 195-235.

MŁYNARSKI M. 1976. - Encyclopedia of Paleoherpetology. Part 7. Testudines. Gustav Fischer Verlag, Stuttgart, 130 p.

MŁYNARSKI M. 1980. — Die Schildkröten des Steinheimer Beckens B. Chelydridae mit einem Nachtrag zu den Testudinoidea. Palaeontographica Supplement B 8 (2): 1-35.

MŁYNARSKi M. \& RočEK Z. 1985. - Chelonians (Reptilia: Testudines) from the Lower Miocene locality Dolnice (Bohemia, Czechoslovakia). Ćasopis pro mineralogii a geologii 30 (4): 39-48.

Pérez-García A. \& Vlachos E. 2014. - New generic proposal for the European Neogene large testudinids (Cryptodira) and the first phylogenetic hypothesis for the medium and large representatives of the European Cenozoic record. Zoological Journal of the Linnean Society 172 (3): 653-719. https://doi. org/10.1111/zoj.12183 
Petrová P., VÍt J. \& ČTYRokÁ J. 2001. — Okrajové vývoje sediment karpatské předhlubně na listech map 1:25.000 Blansko a Tišnov. Scripta Facultatis Scientiarum Naturalium Universitatis Masarykianae Brunensis, Geolology 31: 55-64.

Pomel A. 1847. - Note sur les animaux fossiles découverts dans le département de l'Allier. Bulletin de la Société géologique du France 4: 378-385. https://www.biodiversitylibrary.org/page/54331323

PROCHÁZKA V. J. 1899. — Miocénové ostrovy v krasu Moravském. Rozpravy Ceské Akademie 2: 1-37 (in Czech).

REINACH A. V. 1900. — Schildkrötenreste im Mainzer Tertiärbecken und inbenachbarten, ungefähr gleichalterigen Ablagerungen. Abhandlungen herausgegeben von der Senckenbergischen Natturforschenden Gesellschaft 28: 1-135.

REZ J. 2003. - Strukturni analýza jižni cásti Moravského krasu v lomech Mokrá a okolí. Master Thesis, Masaryk University, $45 \mathrm{p}$, (in Czech with English summary; unpublished).

ReZ J., Melichar R. \& Kalvoda J. 2011. — Polyphase deformation of the Variscan accretionary wedge: an example from the southern part of the Moravian Karst (Bohemian Massif, Czech Republic). Geological Society, London, Special Publications 349 (1): 223-235. https://doi.org/10.1144/SP349.12

RÖSSNER G. 2004. - Community structure and regional patterns in late Early to Middle Miocene Ruminantia of Central Europe. Courier Forschungsinstitut Senckenberg 249: 91-100.

RzeHAK A. 1912. - Beitrag zur Kenntnis der Oncophorachichten Mährens. Verhandlungen der Geologischen Bundesanstalt 1912: 344-347.

RZEHAK A. 1919. - Das Miozän von Brünn. Verhandlungen des Naturforschenden Vereines in Brünn 56: 117-150.

Sabol M., FejFar O., HoráČeK I. \& Čermák S. 2007. — The Early Miocene micromammalian assemblage from Mokrá - 1/2001 Turtle Joint site (Morava, Czech Republic) - preliminary results. Scripta Facultatis Scientiarum Naturalium Universitatis Masarykiane Brunensis, Geology 36: 57-64.

SCHÄFER D. 2013. - Die Schildkröten der Gattung Ptychogaster Pomel, 1847 (Reptilia, Testudines). PhD dissertation, LudwigMaximilians-Universität München, 387 p. (in German with English summary; unpublished).

SCHLEICH H.-H. 1981. — Jungtertiäre Schildkröten Süddeutschlands unter besonderer Berücksichtigung der Fundstelle Sandelzhausen. Courier Forschunginstitut Senckenberg 48: 1-372.

SCHLEICH H.-H. 1988. — Eozäne Schildkrötenreste (Reptilia, Testudines) von St Pankraz am Haunsberg (Österreich). Studia Geologica Salmanticensia Volumen especial 3: 65-184.
SCHLOSSER M. 1910. — Über fossile Wirbeltierreste aus dem Brüxer Braunkohlenbecken. Lotos-Zeitschrift fuer Naturwissenschaften 58: 229-245.

SieBenROCK F. 1914. - Testudo kalksburgensis Toula aus dem Leithagebirge. Jahrbuch der Kaiserlich-Königlichen Geologischen Reichsanstalt 64 (1-2): 357-362.

STAesCHe K. 1931. — Die Schildkröten des Steinheimer Beckens A. Testudinidae. Palaeontographica Supplement 8: 1-17.

Steen D. A., Gibbs J. P., Buhlmann K. A., Carr J. L., Compton B. W., Congdon J. D., Doody J. S., Godwin J. C., Holcomb K. L., JaCKSON D. R., Janzen F. J., Johnson G., Jones M. T., Lamer J. T., Langen T. A., Plummer M. V., Rowe J. W. Saumure R. A., Tucker J. K. \& Wilson D. S. 2012. - Terrestrial habitat requirements of nesting freshwater turtles. Biological Conservation 150 (1): 121-128. https://doi.org/10.1016/j. biocon.2012.03.012

Toula F. 1896. - Ueber neue Wirbelthierreste aus dem Tertiär Oesterreichs und Rumeliens. I. Neue Landschildkrötenreste (Testudo kalksburgensis $\mathrm{n}$. sp.) aus den mediterranen Strandbildungen von Kalksburg bei Wien. Zeitschrift der DeutschenGeologischen Gesellschaft 48 (4): 915-920.

Turtle Taxonomy Working Group [VAn Dijk P. P., IVerson J. B., Rhodin A. G. J., Schaffer H. B. \& BOuR R.]. 2014. Turtles of the world, 7 th edition: Annotated checklist of taxonomy, synonymy, distribution with maps, and conservation status. Chelonian Research Monographs 5: 000.329-000.479. https:// doi.org/10.3854/crm.5.000.checklist.v7.2014

Turtle TaXonomy Working Group [Rhodin A. G. J., IVErson J. B., Bour R., Fritz U., Georges A., Shaffer H. B. \& VAN DijK P. P. 2017. — Turtles of the world: annotated checklist and atlas of taxonomy, synonymy, distribution, and conservation status, $8^{\text {th }}$ edition. Chelonian Research Monographs 7: 1-292. https://doi.org/10.3854/crm.7.checklist.atlas.v8.2017

VAN DER Meulen A. J. \& DaAms R. 1992. - Evolution of Early-Middle Miocene rodent communities in relation to long term paleoenvironmental changes. Palaeogeography, Palaeoclimatology, Palaeoecology 93 (3-4): 227-253. https://doi org/10.1016/0031-0182(92)90099-Q

ZANGERL R. 1969. - The turtle shell, in GANS C. \& Bellasirs A. D. (eds), The Biology of the Reptilia. Volume 1. Academic Press, New York: 311-319.

Ziegler R. 1999. - Order Insectivora, in RÖSSNER G. \& HeISSIG K. (eds), The Miocene Land Mammals of Europe. Verlag Dr. FrierdrichPfeil. Munich: 53-74. 